\title{
Mordenite/Nafion and Analcime/Nafion Composite Membranes Prepared by Spray Method for Improved Direct Methanol Fuel Cell Performance
}

DOI:

10.1016/j.apsusc.2017.02.004

\section{Document Version}

Accepted author manuscript

Link to publication record in Manchester Research Explorer

Citation for published version (APA):

Prapainainar, P., Du, Z., Kongkachuichay, P., Holmes, S., \& Prapainainar, C. (2017). Mordenite/Nafion and Analcime/Nafion Composite Membranes Prepared by Spray Method for Improved Direct Methanol Fuel Cell Performance. Applied Surface Science. https://doi.org/10.1016/j.apsusc.2017.02.004

\section{Published in:}

Applied Surface Science

\section{Citing this paper}

Please note that where the full-text provided on Manchester Research Explorer is the Author Accepted Manuscript or Proof version this may differ from the final Published version. If citing, it is advised that you check and use the publisher's definitive version.

\section{General rights}

Copyright and moral rights for the publications made accessible in the Research Explorer are retained by the authors and/or other copyright owners and it is a condition of accessing publications that users recognise and abide by the legal requirements associated with these rights.

\section{Takedown policy}

If you believe that this document breaches copyright please refer to the University of Manchester's Takedown Procedures [http://man.ac.uk/04Y6Bo] or contact uml.scholarlycommunications@manchester.ac.uk providing relevant details, so we can investigate your claim.

\section{OPEN ACCESS}




\section{Accepted Manuscript}

Title: Mordenite/Nafion and Analcime/Nafion Composite Membranes Prepared by Spray Method for Improved Direct Methanol Fuel Cell Performance

Authors: Paweena Prapainainar, Zehui Du, Paisan

Kongkachuichay, Stuart M. Holmes, Chaiwat Prapainainar

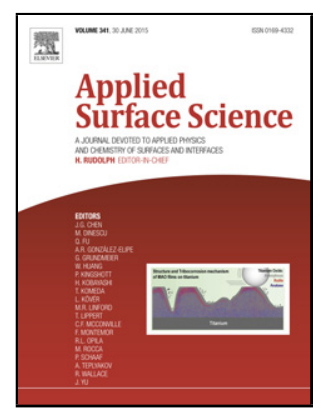

PII: S0169-4332(17)30355-0

DOI: http://dx.doi.org/doi:10.1016/j.apsusc.2017.02.004

Reference: APSUSC 35113

To appear in: $\quad$ APSUSC

Received date: $\quad 14-10-2016$

Revised date: $\quad 31-1-2017$

Accepted date: $\quad$ 2-2-2017

Please cite this article as: Paweena Prapainainar, Zehui Du, Paisan Kongkachuichay, Stuart M.Holmes, Chaiwat Prapainainar, Mordenite/Nafion and Analcime/Nafion Composite Membranes Prepared by Spray Method for Improved Direct Methanol Fuel Cell Performance, Applied Surface Science http://dx.doi.org/10.1016/j.apsusc.2017.02.004

This is a PDF file of an unedited manuscript that has been accepted for publication. As a service to our customers we are providing this early version of the manuscript. The manuscript will undergo copyediting, typesetting, and review of the resulting proof before it is published in its final form. Please note that during the production process errors may be discovered which could affect the content, and all legal disclaimers that apply to the journal pertain. 


\section{Mordenite/Nafion and Analcime/Nafion Composite Membranes Prepared by Spray Method for Improved Direct Methanol Fuel Cell Performance}

Paweena Prapainainar ${ }^{\mathrm{a}, \mathrm{b}}$, Zehui Du ${ }^{\mathrm{a}}$, Paisan Kongkachuichaya, ${ }^{\mathrm{a}, \mathrm{b}}$, Stuart M. Holmes ${ }^{\mathrm{c}}$, Chaiwat Prapainainar $^{\mathrm{d}, \mathrm{e} *}$

a National Center of Excellence for Petroleum, Petrochemicals and Advance Material, Department of Chemical Engineering, Kasetsart University, Bangkok 10900, Thailand.

${ }^{\mathrm{b}}$ NANOTEC Center for Nanoscale Materials Design for Green Nanotechnology and Center for Advanced Studies in Nanotechnology, Applications in Chemical Food and Agricultural Industries, Kasetsart University, Bangkok 10900, Thailand.

${ }^{c}$ School of Chemical Engineering and Analytical Science, The University of Manchester, Manchester M13 9PL, UK.

d Department of Chemical Engineering, King Mongkut's University of Technology North Bangkok, Bangkok 10800, Thailand.

${ }^{\mathrm{e}}$ Research and Development Center for Chemical Unit Operation and Catalyst Design, King Mongkut's University of Technology North Bangkok, Bangkok 10800, Thailand.

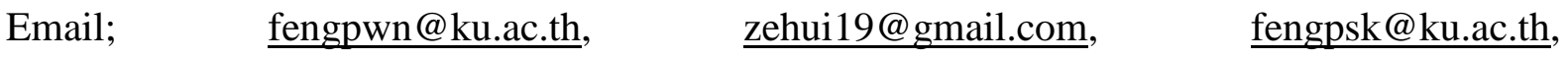
stuart.holmes@manchester.ac.uk, chaiwat.r@eng.kmutnb.ac.th 


\title{
Highlight
}

- Mordenite and analcime were used as fillers in Nafion composite membranes for DMFC.

- The composite membranes were fabricated by spray method.

- Methanol permeability was reduced up to 2-3 times using the composite membranes.

- Mordenite/Naifon membrane showed 2 times higher DMFC performance than Nafion117.

\begin{abstract}
The aim of this work was to improve proton exchange membranes (PEMs) used in direct methanol fuel cells (DMFCs). A membrane with a high proton conductivity and low methanol permeability was required. Zeolite filler in Nafion (NF matrix) composite membranes were prepared using two types of zeolite, mordenite (MOR) and analcime (ANA). Spray method was used to prepare the composite membranes, and properties of the membranes were investigated: mechanical properties, solubility, water and methanol uptake, ion-exchange capacity (IEC), proton conductivity, methanol permeability, and DMFC performance. It was found that MOR filler showed higher performance than ANA. The MOR/Nafion composite membrane gave better properties than ANA/Nafion composite membrane, including a higher proton conductivity and a methanol permeability that was $2-3$ times lower. The highest DMFC performance $\left(10.75 \mathrm{~mW} \cdot \mathrm{cm}^{-2}\right)$ was obtained at $70{ }^{\circ} \mathrm{C}$ and with $2 \mathrm{M}$ methanol, with a value 1.5 times higher than that of ANA/Nafion composite membrane and two times higher than that of commercial Nafion 117 (NF 117).
\end{abstract}

Keywords: Composite membrane; direct methanol fuel cell; spray method; mordenite; analcime; methanol permeability.

\section{Introduction}

Fuel cell technology has been developing rapidly because of a number of advantages that it possesses compared to conventional power sources, such as internal combustion engines or batteries. Fuel cells have higher energy efficiency than diesel or gas engines, and in using 
them, there is no pollution caused, as there is in burning fossil fuels, and no toxic by-product. Therefore, use of fuel cell can reduce greenhouse gases [1,2].

Direct methanol fuel cells (DMFCs) have been an attractive power source for portable electronics applications such as cellular phones, laptop computers, and personal digital assistants [3]. Methanol is used as a fuel source because of its high energy density, low cost, and the fact that it is easily handled and stored. DMFCs work at low and intermediate temperatures and are fed with a dilute solution of methanol [4].

Perfluorosulfonic acid membranes with a hydrophobic backbone and hydrophilic sulfonic acid side chain, such as Nafion, are currently used as proton exchange membranes. This is due to their high proton conductivity, chemical and thermal stability, and mechanical strength [5-8]. Nevertheless, DMFC has some severe problems. One of them is alcohol crossover through the membrane electrolyte resulting in waste of fuel, reduction of methanoloxygen mixed potential at the cathode, and a serious decrease in fuel cell performance $[1,7$, 9].

In order to overcome these problems, a large number of methods have been developed to reduce methanol crossover in DMFC. Optimization has focused on operating parameters such as temperature [9], composition of the cathode feed [1, 2, 10], catalyst loading [3] and membrane thickness [11]. Many researchers have developed new composite membranes and modified the existing materials to alter their transport properties. The modification of Nafion has been studied by employing inorganic filler materials such silica, $\mathrm{TiO}_{2}$, and zeolite.

Many researchers have selected inorganic materials to improve the water retention in the membrane and also to decrease the alcohol crossover [12-15]. Zeolite is a well-defined microporous structure of crystalline aluminosilicates containing silicon and oxygen in its framework. It has some characteristics that are suitable for DMFC. The regular porous structure of zeolite can also reduce alcohol permeation. In addition, the high surface acidity of zeolite provides a high proton conductivity.

Some examples of polymer-zeolite composite membranes for fuel cells are Nafion-Fesilicate-1 membranes [16], Nafion-H-ZSM-5 membranes [14], Nafion-chabazite membranes [17], PVA-mordenite composite membranes [18], Nafion-mordenite hybrid membranes [19], sulfonated poly(ether ether ketone)/Analcime composite membrane [20], and Nafion/Analcime [21].

Among the various kinds of zeolite, mordenite (MOR) and analcime (ANA) have been great candidates for fabricating composite membranes. They are hydrophilic substances with molecular sieve properties $[5,12]$, preferring to adsorb water to alcohol and providing a good 
proton pathway through the membrane while blocking the diffusion path of alcohol inside a Nafion composite membrane. In addition, mordenite and analcime are stable in acid and have high temperature tolerance. In our previous work, Yoonoo and coworkers [5] prepared Nafion/mordenite composite membrane to reduce methanol diffusion across the DMFC. The produced membranes exhibited reductions in methanol permeability of $21.62 \%$ and $4.27 \%$ at $30{ }^{\circ} \mathrm{C}$ and $70{ }^{\circ} \mathrm{C}$, respectively, compared to a recast Nafion membrane. Kongkachuichay and coworkers [21] used Analcime and Faujasite as the zeolite in Nafion/zeolite composite membranes for PEMFCs. The proton conductivity of the Nafion/ANA composite membrane was enhanced 11 times at room temperature and 6.8 times at $80{ }^{\circ} \mathrm{C}$, compared to Nafion membrane. It was reported that this enhancement might come from hydration inside the 3D channels of zeolite, with the hydrated water improving the proton motion or hydronium ion motion via the exchange of protons between hydronium ion and water molecules.

In this study, Nafion composite membranes with two fillers, mordenite and analcime, were fabricated by spray method. The properties of membranes with different fillers were studied and compared. The obtained composite membranes were characterized using SEM and mechanical test, and in term of solubility, water uptake, ion-exchange capacity (IEC), proton conductivity, methanol uptake, and methanol permeability. The DMFC performance test was also performed.

\section{Experimental}

\subsection{Materials}

Sodium aluminate $\left(\mathrm{Al}_{2} \mathrm{O}_{3} 50-56 \%, \mathrm{Na}_{2} \mathrm{O} 40-45 \%\right)$, 3-mercaptopropyl triethoxysilane (MPTES) and hexamethylenimine $(98.0 \%)$ were purchased from Sigma-Aldrich. Sodium silicate (neutral solution QP) was purchased from Panreac. Sodium hydroxide (97.0 \%), aluminumtrichloride (95.0\%), and hydrogen peroxide (35 wt. \%) were purchased from Ajax Finechem. A 20 wt. \% Nafion solution was purchased from Ion Power. Sulfuric acid, ethanol, methanol, N, N-dimethylformamide, dichloromethane, ammonium cholride, toluene were purchased from ACI Labscan. De-ionized water was used throughout the study.

\subsection{Methods}


2.2.1 Synthesis of mordenite and analcime

Two types of zeolite were synthesized in this work: mordenite (MOR) and analcime (ANA). The corresponding synthesis procedures are described below;

\subsubsection{MOR synthesis}

The synthesis method was developed from the method of Corma and coworkers, using hexamethylenimine (HMI) as a template mixed with sodium silicate $\left(\mathrm{Na}_{2} \mathrm{SiO}_{3}\right)$ as a silica source, sodium aluminate $\left(\mathrm{NaAlO}_{2}\right)$ as a alumina source, and sodium hydroxide $(\mathrm{NaOH})$ as an alkali source [22]. The crystallization occurred in an autoclave operated hydrothermally and under agitation as follows. First, a mixture of $0.92 \mathrm{~g} \mathrm{NaAlO}_{2}$ and $0.60 \mathrm{~g} \mathrm{NaOH}$ was dissolved in $124.2 \mathrm{ml}$ of $\mathrm{H}_{2} \mathrm{O}$. Then, $7.61 \mathrm{~g} \mathrm{HMI}$ and $25.639 \mathrm{~g} \mathrm{Na}_{2} \mathrm{SiO}_{3}$ were added to the solution using vigorous stirring for $30 \mathrm{~min}$. After that, the resulting gels were introduced into $60 \mathrm{ml}$ of PTFElined stainless-steel autoclaves, rotated at $60 \mathrm{rpm}$, and heated at $170{ }^{\circ} \mathrm{C}$ for $24 \mathrm{~h}$. After quenching the autoclaves in cold water, the solution was centrifuged. A portion of the solids was calcined in air at $580 \mathrm{~K}$ for $5 \mathrm{~h}$ to obtain MOR-Na.

\subsubsection{ANA synthesis}

The synthesis method was developed from that of Kim et al. using materials similar to the first method but without HMI as the template [23]. The crystallization occurred in an autoclave with hydrothermal system as follows: $4 \mathrm{~g}$ of water was mixed with $1.9 \mathrm{~g}$ of $\mathrm{NaOH}$ and stirred until the solid dissolved. Then, $1.43 \mathrm{~g}$ of $\mathrm{NaAlO}_{2}$ was added into the solution and stirred until it too was dissolved. After that, $64.5 \mathrm{ml}$ of water and $19.94 \mathrm{~g}$ of $\mathrm{Na}_{2} \mathrm{SiO}_{3}$ were added into the solution and stirred for $30 \mathrm{~min}$. The resulting gels were introduced into PTFElined stainless-steel autoclaves and heated at $170^{\circ} \mathrm{C}$ for $24 \mathrm{~h}$. After quenching the autoclaves in cold water, the solution was filtered and washed until $\mathrm{pH}$ was less than 10 and dried at 100 ${ }^{\circ} \mathrm{C}$ to obtain ANA-Na.

\subsubsection{Grinding of MOR and ANA}

Grinding was used to reduce the particle size and obtain a homogeneous size of particles. The grinding procedure can be described in the following steps. First, $4 \mathrm{~g}$ of MOR (or ANA) and $10 \mathrm{ml}$ of $0.5 \mathrm{~mm}$ zirconia ball grinding media were added into a container. Then, $15 \mathrm{ml}$ distilled water was added to the container. Grinding speed was fixed by speed control. The sample was ground for 200 min to obtain a homogeneous distribution of particles of the smallest possible size. 


\subsubsection{Protonating of MOR and ANA}

MOR and ANA surfaces were transformed into $\mathrm{H}^{+}$form in order to provide ionic paths for $\mathrm{H}^{+}$to travel from anode to cathode. To this end, MOR-Na and ANA-Na were treated to change $\mathrm{Na}^{+}$to $\mathrm{H}^{+}$. The protonating method followed the procedure of Zanjanchi et al. [24]. The protonating procedure can be described as follows. First, $2 \mathrm{~g}$ of the MOR-Na (or ANA-Na) powder was stirred in $100 \mathrm{ml}$ of $1 \mathrm{M} \mathrm{NH}_{4} \mathrm{Cl}$ solution at room temperature for $24 \mathrm{~h}$. At this stage, $\mathrm{Na}^{+}$was replaced by $\mathrm{NH}_{4}{ }^{+}$and MOR-Na (or ANA-Na) became MOR-NH 4 (or ANA$\mathrm{NH}_{4}$ ) [25]. The suspension was subsequently vacuum filtered. Then, the sample was washed with deionized water and dried at $105^{\circ} \mathrm{C} . \mathrm{MOR}-\mathrm{NH}_{4}$ (or ANA-NH 4 ) was then calcined in a furnace at $550{ }^{\circ} \mathrm{C}$ for $5 \mathrm{~h}$ with a heating rate of $2{ }^{\circ} \mathrm{C} \cdot \mathrm{min}^{-1}$. At this point, $\mathrm{NH}_{3}$ was released from $\mathrm{NH}_{4}{ }^{+}$and left $\mathrm{H}^{+}$on the surface. In this stage, MOR-NH 4 was converted to MOR-H (ANA-NH 4 was converted to ANA-H).

\subsubsection{Functionalization of zeolites}

In order to enhance the properties of the interface between polymer matrix and zeolite fillers, surface modification of zeolite was required by using silane coupling agent. The silane coupling agent used in this work was 3-mercaptopropyltriethoxysilane (MPTES). Zeolites before and after functionalization were investigated to ensure successful modification. The procedure of surface modification by MPTES as in the following steps. Catalyst solution was prepared by dissolving $1 \mathrm{~g}$ of aluminum (III) chloride in $20 \mathrm{ml}$ of ethanol at $70{ }^{\circ} \mathrm{C}$ until completely dissolved. Then $20 \mathrm{ml}$ of toluene was added. A silane solution was prepared by mixing $4 \mathrm{ml}$ of MPTES with $40 \mathrm{ml}$ of toluene and stirred for $30 \mathrm{~min}$. Then, $5 \mathrm{ml}$ of the catalyst solution was mixed with the silane solution, followed by the addition of $2 \mathrm{~g}$ of MOR-H (or ANA-H) to the mixture. The resulting solution was refluxed at $110{ }^{\circ} \mathrm{C}$ for $24 \mathrm{~h}$ under stirring condition. From the solution, the zeolite was separated by using a centrifuge (6000 rpm), and it was then rinsed with ethanol and deionized water to remove the silane residues. The filtrated solid was dried at $105{ }^{\circ} \mathrm{C}$ for $24 \mathrm{~h}$. Functionalized zeolite was oxidized by $30 \mathrm{wt} \% \% \mathrm{H}_{2} \mathrm{O}_{2}$ under stirring condition for $24 \mathrm{~h}$ at room temperature in order to convert the $-\mathrm{SH}$ groups into $-\mathrm{SO}_{3}$ groups at the surface of the zeolites. MOR after surface treatment was called MOR-MPTES and ANA after surface treatment was referred to as ANA-MPTES.

\subsubsection{Composite membrane preparation}


The composite membranes were fabricated by spray method, which was developed based on the spray-coated technique utilized by Sun and coworkers [26]. The spray procedure consisted of the following steps. First, the required spraying gun was connected with a 2 barg nitrogen gas system. Using a temperature controlled, the mold template temperature was set to $100{ }^{\circ} \mathrm{C}$. Membrane solution was prepared by following the procedure from our previous work [27]. The solution was poured into the spray gun container and sprayed on the hot template; the resulting membrane dried immediately after been sprayed. The template was cooled at ambient temperature. Several drops of deionized water were added at the contact point between the membrane and the template to assist in the removing of the membrane. Subsequently, the membrane was removed from the template and then heated to $150^{\circ} \mathrm{C}$ for $4 \mathrm{~h}$ for annealing. The average thickness of the fabricated membranes was measured using a micrometer at nine different points across the membrane.

\subsection{MOR and ANA Characterization}

The particle size of MOR and ANA were examined by using a Mastersizer 2000 (Malvern Instruments Ltd.). Meanwhile, MOR and ANA crystalline structures were characterized using X-ray diffractrometry obtained with a BRUKER Advance A25 equipped with $\mathrm{Cu}-\mathrm{K} \alpha$ radiation $\left(1.5418 \AA\right.$ ). These XRD patterns were obtained at $2 \theta$ between $5^{\circ}$ and $40^{\circ}$. Fourier transform infrared spectrophotometry (FTIR, BRUKER TENSOR 27) was used to investigate the functional groups on MOR and ANA before and after surface modification at wave numbers of $400-4,000 \mathrm{~cm}^{-1}$. Thermogravimetric analysis (TGA, SDT 2960) was used to determine the quantity of silane coupling agent modified on MOR and ANA. Testing was performed in air with a flow rate of $100 \mathrm{~cm}^{3} \mathrm{~min}^{-1}$, a heating rate of $10{ }^{\circ} \mathrm{C} \mathrm{min}^{-1}$, and a temperature range of $25-1,100^{\circ} \mathrm{C}$. Surface area and pore size distribution of MOR and ANA were investigated by $\mathrm{N}_{2}$ sorption measurement using Autosorb-1. The sample was degassed at $150{ }^{\circ} \mathrm{C}$ for $15 \mathrm{~h}$ under vacuum before $\mathrm{N}_{2}$ sorption at $77 \mathrm{~K}$. The morphology of composite membranes were investigated by scanning electron microscope (SEM, FEI QUANTA 450) equipped with Oxford X-Max EDX detector. Using a universal testing machine (Instron 4206), the mechanical properties of membranes were investigated. Each sample was cut into a size of $10 \mathrm{~mm} \times 50 \mathrm{~mm}$ with a gauge length of $30 \mathrm{~mm}$ and tested according to ASTM D882. A total of five specimens were tested for each sample under dry condition at a rate of $5 \mathrm{~mm} / \mathrm{min}$.

\subsection{Membrane characterization}

\subsubsection{Solubility}


Solubility is an important indicator that reflects the chemical resistance of the membrane. The solubility of membrane was determined by following the procedure of Moore and Martin [28]. First, $50 \mathrm{mg}$ of the membrane was added to $10 \mathrm{ml}$ of 50:50 methanol-water solution and sonicated in an ultrasonic bath for $1 \mathrm{~h}$. The water in the ultrasonic bath was changed every $30 \mathrm{~min}$ to retain room temperature. To remove undissolved solid, the solution was filtered through Whatman No.1 filter paper. The obtained solid residue after evaporation at $100{ }^{\circ} \mathrm{C}$ was weighed, and the percent soluble was calculated by equation (1):

$$
\% \text { Solubility }=\frac{\text { weight of residue }}{\text { weight of membrane }} \times 100 \%
$$

\subsubsection{Water uptake}

Water uptake was used to investigate the behavior of the composite membrane when put in contact with water. It was determined by measuring the weight change between dry and wet membranes. The procedure from Theampetch's work and Kongkachuichay's work [20, 29] was followed. Membrane samples were dried at $80{ }^{\circ} \mathrm{C}$ in a vacuum oven for $24 \mathrm{~h}$ before the dry weight was measured. Then the dry membranes were kept in a desiccator. The samples were soaked in deionized water at room temperature for $24 \mathrm{~h}$. After removal of the excess moisture by Whatman No. 1 filter paper, the samples were reweighed to obtain the wet weight, and \%water uptake was calculated from equation (2)

$$
\% \text { Water uptake }=\frac{\text { wet weight }- \text { dry weight }}{\text { dry weight }} \times 100 \%
$$

where wet weight (g) and dry weight (g) are the weights of the fully hydrated and the anhydrous membranes, respectively.

The alcohol uptake was examined using a similar procedure: by soaking the membrane of known weight in methanol of a known concentration for $24 \mathrm{~h}$.

\subsubsection{Ion-exchange capacity}

Representing the quantity of acid equivalents per gram of polymer [20, 29], ionexchange capacity is an indirect and reliable approximation of the proton conductivity of the membranes [15]. Here, the ion-exchange capacity of the membrane was determined by an acidbased titration method. The procedure of Theampetch's work [29] was followed. First, $50 \mathrm{mg}$ 
samples of treated membrane were immersed in $10 \mathrm{ml}$ of $\mathrm{NaCl}$ solution $(1 \mathrm{M})$ for $24 \mathrm{~h}$ to replace all $\mathrm{H}^{+}$with $\mathrm{Na}^{+}$. The solution was titrated with $0.01 \mathrm{M} \mathrm{NaOH}$ using phenolphthalein as an indicator to determine the amount of $\mathrm{H}^{+}$in the solution. The ion-exchange capacity was calculated sung equation (3):

$$
\mathrm{IEC}=\frac{\mathrm{C}_{\mathrm{NaOH}} \mathrm{V}_{\mathrm{NaOH}}}{\mathrm{M}_{\mathrm{dry}}}
$$

where $\mathrm{C}_{\mathrm{NaOH}}$ is the concentration of $\mathrm{NaOH}(\mathrm{M}), \mathrm{V}_{\mathrm{NaOH}}$ is the volume of $\mathrm{NaOH}$ used in the titration ( $\mathrm{ml})$, and $\mathrm{M}_{\mathrm{dry}}$ is the weight of the dry membrane (g).

\subsubsection{Proton conductivity}

The proton conductivity test using two-electrode method is a widely used method for measuring membrane conductivity in the transverse direction. The measurement was done under potentiostatic conditions, that is, a small potential perturbation was applied to the cell. In this work, the proton conductivity was characterized at different temperatures. The electrolyte container was surrounded by a water jacket to ensure a constant temperature during the measurement. Before measurement, the fabricated membrane specimens were treated by boiling in deionized water, then in 5 wt. $\%$ of $\mathrm{H}_{2} \mathrm{O}_{2}$, subsequently, in $1 \mathrm{M} \mathrm{H}_{2} \mathrm{SO}_{4}$ solution, and finally in deionized water. Consequently, the membranes were immersed in $1 \mathrm{M} \mathrm{H}_{2} \mathrm{SO}_{4}$ for at least $24 \mathrm{~h}$ before prior to the measurement. Each membreane was measured nine time. The procedure followed was that of Theampetch's work [29]. First, $20 \mathrm{ml}$ of $1 \mathrm{M} \mathrm{H}_{2} \mathrm{SO}_{4}$ was added into the electrolyte container. The potentiostat analyzer was set at a frequency from $1 \mathrm{mHz}$ to $100 \mathrm{~Hz}$ and at an amplitude of $5 \mathrm{mV}$. It was set up by connecting the counter electrode to the reference electrode and the sample to the working electrode. The membrane was placed between the two electrodes. The data was collected in a Nyquist Z' vs Z' plot. With all of the above, the proton conductivity $(\sigma)$ was calculated using equation (4):

$$
\sigma=\frac{\mathrm{d}}{\mathrm{RA}}
$$

where $\mathrm{d}$ is the membrane thickness $(\mathrm{cm}), \mathrm{R}$ is the membrane resistance $(\mathrm{Ohm})$, an $\mathrm{A}$ is the crossectional area of electrode $\left(\mathrm{cm}^{2}\right)$. In this experiment, the resistance of each membrane was 
measured for three points, with each point being measured and three times making a total of nine measurement for each membrane.

\subsubsection{Alcohol permeability}

In this work, diffusion technique was used. The feed side contained $1 \mathrm{M}$ methanol, and the permeate side contained water. Methanol diffused across the membrane due to the concentration gradient. The methanol concentration caused by the crossover in the permeate side was measured as a function of time. The diffusion cell consisted of a feed compartment and a permeate compartment. On the feed side, a $2000 \mathrm{ml}$ tank of methanol was connected to the diffusion cell by plastic tubing, and the methanol solution was circulated by a centrifugal pump. On the permeate side, a bottle containing $250 \mathrm{ml}$ of deionized water was connected with the cell, and the dilute solution was circulated by a centrifugal pump. Before measurement, the membrane was treated and kept in deionized water for $24 \mathrm{~h}$. The hydrated membrane was inserted in the diffusion cell with sealing gaskets to ensure that there was no leakage. The cell was bolted together and connected to methanol solution tank $(2000 \mathrm{ml})$ and deionized water tank $(250 \mathrm{ml})$. To control the temperature, the feed and permeate were then placed in the water bath. At the beginning of the operation, methanol solution was fed to the feed size for $5 \mathrm{~min}$, then the pump on permeate side was switch on. Consequently, the first $1 \mathrm{ml}$ sample was collected by a pipette from the permeate side. Subsequently, samples were collected and kept in glass vials at 5, 30, 60 and $90 \mathrm{~min}$, then they were analyzed by $\mathrm{GC}$ for the methanol content. The rate of methanol permeation $\left(\mathrm{P}, \mathrm{cm}^{2} \mathrm{~s}^{-1}\right)$ was calculated using equation (5):

$$
P=\frac{K V L}{\mathrm{SC}_{\mathrm{A} 0}}
$$

where $\mathrm{K}$ is the slope of the curve of the concentration in the permeate compartment vs. time plot $\left(\mathrm{mol} \mathrm{cm} \mathrm{s}^{-1}\right), \mathrm{V}$ is the volume of the permeate compartment $\left(\mathrm{cm}^{3}\right), \mathrm{S}$ is the membrane area $\left(\mathrm{cm}^{2}\right), \mathrm{L}$ is the membrane thickness $(\mathrm{cm})$, and $\mathrm{C}_{\mathrm{A} 0}$ is the initial concentration of methanol in the feed compartment $\left(\mathrm{mol} \mathrm{cm}{ }^{-3}\right)$.

The operation temperature was varied as so to be either $30^{\circ} \mathrm{C}$ or $70{ }^{\circ} \mathrm{C}$.

\subsubsection{Membrane electrode assembly preparation and DMFC performance test}

An assembly of anode, membrane, and cathode was arranged for a hot-pressing process. The assembly was sandwiched between two backing plates called the membrane electrode 
assembly (MEA). Deionized water was continuously fed to both sides of the MEA and the cell was kept at $80^{\circ} \mathrm{C}$ ensuring fully hydrated membrane in the MEA.

For the DMFC preformance test, methanol solution was delivered to the anode side of the fuel cell by a peristaltic pump. Air was supplied on the cathode side, the air flow rate being controlled by an air flow meter. The potential and current were monitored by an ammeter and a voltmeter, respectively. An external power supply was used for controlling current flowing through the testing unit, the operative temperature was controlled by a temperature controller conjunction with a thermocouple and electric heaters. The membrane area was $4.5 \mathrm{~cm} \times 4.5$ $\mathrm{cm}$. Pt-Ru/Carbon paper electrode $\left(2 \mathrm{mg} \mathrm{cm}^{-2}\right)$ was used as the anode, and 60\% $\mathrm{Pt} / \mathrm{Carbon}$ paper electrode $\left(0.5 \mathrm{mg} \mathrm{cm}^{-2}\right)$ was used as cathode. An air flowrate of $1 \mathrm{~L} \cdot \mathrm{min}^{-1}$ and a methanol solution feed rate of $5 \mathrm{ml} \cdot \mathrm{min}^{-1}$ were also used.

\section{Results and discussion}

After preparing and characterizing the composite membrane, the results were separated to two sections: characterization of MOR and ANA and characterization of membranes.

\subsection{Characterization of MOR and ANA}

In this section, synthesized MOR and ANA after MPTES surface modification were characterized in terms of particle size, surface area, pore volume, XRD, FTIR, and TGA.

\subsubsection{The particle sizes of MOR and ANA}

The particle sizes of the synthesized MOR and ANA before and after grinding were measured by using a Mastersizer 2000 (Malvern Instruments Ltd.). The grinding method is popular and widely used in particle reduction due to its simplicity and efficiency. In the process of wet grinding, particles were ground in slurry form to break apart the genuine particles. Additionally, the wet grinding method can produce submicron-size particles and can protect agglomeration of particles [29]. The smaller the particle as a filler in membrane fabrication, the more uniformly dispersed is the membrane matrix obtained. MOR-s and ANA-s represent MOR and ANA as received from the synthesis and before grinding, while MOR and ANA represent MOR and ANA after grinding. The particle size distribution of MOR before grinding was trimodal with peaks in the ranges of $0.1-0.3 \mu \mathrm{m}, 0.4-3 \mu \mathrm{m}$, and $4-30 \mu \mathrm{m}$ (see Figure 1 (a)). However, it could be observed from Figure 1 (a) that most particles had sizes in the 
range of $4-30 \mu \mathrm{m}$. After grinding, the particle size was in the range of $0.1-3 \mu \mathrm{m}$ as shown in Figure 1 (b). It was found that the size distribution was bimodal in distribution.

For ANA, the particle size was in two ranges of $0.4-3 \mu \mathrm{m}$ and $6-80 \mu \mathrm{m}$ as shown in Figure 1 (c). After grinding, the particle size distribution was reduced to the range of $0.1-10$ $\mu \mathrm{m}$ as shown in Figure 1 (d). As with the corresponding MOR size distribution, it was also bimodal.

\subsubsection{Surface area and pore volume characterization}

$\mathrm{N}_{2}$ sorption was used to determine the surface area, pore volume, and pore size diameter of the synthesized MOR and ANA. Coarse ANA and ground ANA were referred to as ANA-s and ANA. Coarse MOR and ground MOR were represented by MOR-s and MOR. Data for surface area, pore volume, and pore size diameter of samples are summarized in Table 1. Upon grinding, the surface area of ANA increased from 15.70 to $34.20 \mathrm{~m}^{2} \mathrm{~g}^{-1}$, while that of MOR increased from 137.00 to $175.00 \mathrm{~m}^{2} \mathrm{~g}^{-1}$. The pore volume increased from 0.017 to 0.095 $\mathrm{cm}^{3} \mathrm{~g}^{-1}$ and 0.150 to $0.286 \mathrm{~cm}^{3} \mathrm{~g}^{-1}$ for ANA and MOR, respectively. Data for pore diameter of both ANA and MOR before and after grinding confirmed that all samples were microporous [30].

\subsubsection{XRD characterization}

In this work, XRD was used to examine the crystallinity of MOR and ANA before and after grinding and after surface modification. XRD results of MOR and ANA are shown in Figure 2. The diffraction patterns corresponded to the reflection of MOR and ANA [31]. It was observed that all diffraction pattern of the samples after grinding, protonating, and MPTES surface modification remained the same. This meant that the crystallinity of MOR and that of ANA were not destroyed. These results were consistent with those of our previous work [27, 29].

\subsubsection{SEM characterization}

SEM was used to identify the morphology of MOR and ANA in each of the following stages: coarse, ground, protonated, and surface modified with MPTES. Figure 3 and Figure 4 show SEM images of MOR and ANA, respectively. It could be observed that coarse and ground MOR clearly showed differences in particle size. Coarse MOR (Figure 3 (a)) exhibited a 
bimodal particle size distribution, which was in agreement with the previous Mastersizer measurement. Ground MOR (Figure 3 (d)) was of an irregular shape and a smaller size. MOR modified by MPTES (Figure 3 (c)) showed agglomeration of particles that may be due to adhesion between primary particles and formation of new aggregated structures [29]. Moreover, both coarse and ground MOR in the protonated stage (Figure 3 (b) and (e)) did not show significantly different shape to those without protonation (Figure 3 (a) and (d)).

Coarse ANA particles were spherical in shape, with facets, and the size obtained was in agreement with the previous Mastersizer measurement. Ground ANA (Figure 4(d)) was of a smaller size than coarse ANA, and the structure was broken as a result of grinding process. ANA particles modified with MPTES were found to have agglomerated. The same reasoning as given for modified MOR can be applied to explain the results.

\subsubsection{FTIR characterization}

The functional groups of MOR and ANA before and after MPTES surface modification were characterized by FTIR. The surface modification was for improving properties of interfaces between Nafion matrix and the zeolite filler. The FTIR spectra of MOR in coarse condition and ground condition are shown in Figure 5 (a) and (b). The band around $3100-$ 3500 and that at $1630 \mathrm{~cm}^{-1}$ were the stretching and bending vibrations of the hydroxyl group, respectively $[27,32]$. The bands in the range of $920-1250 \mathrm{~cm}^{-1}$ corresponded to the internal asymmetric stretching of tetrahedral groups, while those in the range of $650-720 \mathrm{~cm}^{-1}$ corresponded to the internal symmetric stretching. The band in the range of $450-500 \mathrm{~cm}^{-1}$ was indicative of $\mathrm{T}-\mathrm{O}$ bonds ( $\mathrm{T}=\mathrm{Si}$ or $\mathrm{Al}$ with each metal ion bonded to four oxygen atoms) [27, $30,32,33]$. The band at $550-590 \mathrm{~cm}^{-1}$ was associated with the structural order of tetrahedral ring and/or a octahedral ring [32]. After surface treatment with MPTES, the peak around 2884 $-2973 \mathrm{~cm}^{-1}$ could be observed, and this peak is associated with the asymmetric stretching of $\mathrm{CH}_{2}$ from the propyl groups of the grafted silane [27, 34].

The FTIR spectra of ANA in coarse condition and those of that ANA which has already been ground are also shown in Figure 5 (c) and (d). The band at around $937 \mathrm{~cm}^{-1}$ corresponded to the internal vibration of tetrahedral $\mathrm{TO}_{4}$ of ANA. The band at about $1100 \mathrm{~cm}^{-1}$ was due to the vibrations of the external linkages between tetrahedral groups. Symmetrical stretching of T-O-T was attributed to the bands at 445, 620, and $737 \mathrm{~cm}^{-1}$ [35]. For ANA-s-MPTES and ANA-MPTES, the band around $2884-2973 \mathrm{~cm}^{-1}$ was detected as asymmetric stretching of $\mathrm{CH}_{2}$ from the propyl groups after surface modification with MPTES [27, 36]. 
For other works that reported the conversion of $-\mathrm{SH}$ group to $-\mathrm{SO}_{3} \mathrm{H}$ group by oxidation were the works from Ren [37] and Kim [38]. Ren and coworkers (2006) used silane coupling agent to enhance the proton conductivity of composite membrane [37]. They reported the treatment of thiol group (-SH) in mercaptopropyl methyldimethoxysilane using $\mathrm{H}_{2} \mathrm{O}_{2}$. The $-\mathrm{SH}$ group was changed to $-\mathrm{SO}_{3} \mathrm{H}$ group after oxidizing with $30 \mathrm{wt} . \% \mathrm{H}_{2} \mathrm{O}_{2}$ solution for $1 \mathrm{~h}$ at room temperature. Kim and coworkers (2010) also reported the change of -SH group into SO3H group by oxidation with 10 wt. $\% \mathrm{H}_{2} \mathrm{O}_{2}$ [38].

\subsubsection{TGA characterization}

In order to determine the amount of treated silane on the zeolite surface, TGA was used. TGA curves of both unmodified zeolite and modified zeolite are shown in Figure 6. The weight loss at temperature below $250{ }^{\circ} \mathrm{C}$ was due to the loss of water in the interlayer and the weakly adsorbed water [27, 38]. Results temperatures in the range between $250-800{ }^{\circ} \mathrm{C}$ could be attributed to the loss of the strongly bond water and the dehydroxylation of the external zeolite surface as shown in the equation (6) [8]:

$$
2 \mathrm{SiOH} \gg>\mathrm{Si}-\mathrm{O}-\mathrm{Si}+\mathrm{H}_{2} \mathrm{O}
$$

For MPTES modified MOR (MOR-MPTES), the $15 \%$ weight loss observed in the temperature range $25-250{ }^{\circ} \mathrm{C}$ was due to the evaporation of weakly adsorbed water, whereas the additional loss of $9 \%$ between $250{ }^{\circ} \mathrm{C}$ and $650{ }^{\circ} \mathrm{C}$ was due to the decomposition of the organic species attached to MOR surface after modification. The data from TGA was used to calculate \% silane treatment. For modified ground MOR (MOR-MPTES), the weight loss due to water evaporation between $25^{\circ} \mathrm{C}$ and $250{ }^{\circ} \mathrm{C}$ was $10 \%$, as shown in Figure 6 , and about $7 \%$ weight loss occurred between 250 and $650{ }^{\circ} \mathrm{C}$ for the organic species.

For ANA-s-MPTES and ANA-MPTES, that is MPTES-modified coarse ANA and MPTES-modified ground ANA, the loss of adsorbed water in the range of $25-250{ }^{\circ} \mathrm{C}$ were $10 \%$ for the former and $13 \%$ for the latter. Corresponding values for the degradation of organic species were $14 \%$ and $10 \%$, shown in Figure 6 . The minor weight loss observed beyond 800 ${ }^{\circ} \mathrm{C}$ may be due to a high temperature solid-state transformation or because of oxide formation [32]. Data for total weight loss and percentage of silane treatment of all samples are summarized in Table 2. 


\subsection{Membrane characterization}

In this section, the results of membrane characterization of ANA/Nafion composite membrane (ANA/NF), MOR/Nafion composite membrane (MOR/NF), Nafion (NF), and commercial Nafion 117 (NF117) are presented. ANA/NF, MOR/NF, and NF were prepared by spray method. The average thicknesses calculated based on data obtained from nine positions along each membrane are summarized in Table 3.

\subsubsection{Morphology of composite membranes}

The SEM/EDS images in Figures 7-10 show the morphology and particle dispersion of the composite membranes. The $5 \mathrm{wt} . \%$ of ground MOR and ground ANA were used as fillers in composite membranes, which were then referred to as MOR/NF and ANA/NF, respectively. For EDS images, red and blue dots were silicon $(\mathrm{Si})$ and aluminium (Al), respectively, representing zeolite particles (MOR or ANA). Green and white dots were fluorine (F) and sulfur (S) representing Nafion polymer.

In this work, MOR and ANA were added into a Nafion matrix in order to reduce the methanol crossover through the membrane during membrane solution preparation. Spray method was used to prepare the membranes as it was expected to improve the homogeneous dispersion of filler particles in the Nafion matrix and reduce the particle separation from the matrix which was found in the composite membrane fabricated from the solution casting method [5, 27].

\subsubsection{Solubility}

Solubility is one of the important indicator for proton-conducting membrane properties, and a solubility test is used to reflect chemical resistance of the membrane. Moore and Martin [28] defined a good conducting membrane as one either dry or wet, which is insoluble in a solvent. This means the membrane should have a solubility less than 5\% [28]. Looking at the data in Figure 11, it can be seen that all the membrane prepared by spray method exhibit good chemical resistance as all membranes have solubility lower than $5 \%$ as Moore and Martin's suggestion [28].

\subsubsection{Water uptake}


Water uptake is one of the important parameters affecting the performance of PEM. While water molecules in a matrix are used for proton transport, water uptake is required to not be too great because excess water uptake may lead to low mechanical stability and other undesirable mechanical properties [39]. Xu and coworkers reported the water uptake of PEM to be in the range of $2.51-67.23 \%$ at $25^{\circ} \mathrm{C}$.

Figure 12 shows that ANA/NF composite membrane could adsorb higher water content than MOR/NF composite membrane. This may be due to the stronger polarity of ANA as it has a lower $\mathrm{Si} / \mathrm{Al}$ ratio than MOR (2 relative to 10 ). Thus, more water was absorbed into the ANA/NF composite membrane [21].

\subsubsection{Ion-exchange capacity}

The ion-exchange capacity (IEC) is an indirect indication of proton conductivity [15]. Figure 13 gives IEC values of the membranes. It can be observed that all composite membranes had higher IEC than NF and commercial membranes, and this fact is due to the presence of $-\mathrm{SO}_{3} \mathrm{H}$ groups on the zeolite [15].

It was also observed that IEC value of MOR/NF $\left(0.88 \mathrm{Meq}^{-1}\right)$, again see Figure 13, was slightly higher than that of ANA/NF $\left(0.82 \mathrm{Meq} \mathrm{g}^{-1}\right)$. This was due to the higher surface area of MOR $\left(175.00 \mathrm{~m}^{2} \mathrm{~g}^{-1}\right)$ relative to ANA $\left(34.20 \mathrm{~m}^{2} \mathrm{~g}^{-1}\right)$.

\subsubsection{Proton conductivity}

Figure 14 shows proton conductivity of the composite membranes prepared via spray method under testing temperatures of 30,50 , and $70{ }^{\circ} \mathrm{C}$. At $30{ }^{\circ} \mathrm{C}, \mathrm{ANA} / \mathrm{NF}$ and $\mathrm{MOR} / \mathrm{NF}$ composite membranes showed comparable results: the former giving 0.0494 and the latter giving $0.0501 \mathrm{~S} \cdot \mathrm{cm}^{-1}$. However, ANA/NF exhibited slightly higher proton conductivity than MOR/NF when temperature was raised to $50{ }^{\circ} \mathrm{C}$ or $70{ }^{\circ} \mathrm{C}$.

A number of researchers investigated the proton conductivity of membranes and reported that the proton conductivity of composite membranes were improved according to the existing of proton conducting group such as sulfonic acid, phosphoric acid, and imidazole. The presence of the proton conducting group benefited the proton migration through the membrane [40-42].

\subsubsection{Methanol uptake}


In order to develop a membrane with low methanol permeability, it is necessary to examine methanol uptake in the membrane structure [43]. Figure 15 shows the methanol uptake of the membranes using $1 \mathrm{M}$ and $2 \mathrm{M}$ methanol concentration. For all membranes, it was found that the uptake for the lower methanol concentration was lower than that obtained using the higher concentration.

Comparing the composite membranes to NF and NF117, it was found that the composite membranes had a lower methanol uptake than NF and NF117 at both $1 \mathrm{M}$ and $2 \mathrm{M}$ methanol concentrations. Thus, it can be concluded that the presence of MOR and ANA particles was able to enhance the degree to which the membrane acts as a barrier to methanol molecules. This was attributed to the tortuousness of the voids of added particles resulting in more methanol diffusion path ways through the membrane [15, 44, 45].

ANA/NF had higher methanol uptake than MOR/NF both at low and high methanol concentrations (1 M and $2 \mathrm{M})$. This may be due to the intrinsic properties of ANA and MOR or may be because ANA has larger pore diameter (15.00 $⿱$ ) than MOR (5.16 $\AA$ ). Therefore, more methanol was able to be adsorbed in the voids of ANA/NF than in the MOR/NF composite membrane [46].

\subsubsection{Methanol permeability}

Methanol permeability of composite membranes prepared by spray method were studied under testing temperatures of $30^{\circ} \mathrm{C}$ and $70{ }^{\circ} \mathrm{C}$ : see Figure 16 . The results of methanol permeability are shown in Figure 16 . At $30{ }^{\circ} \mathrm{C}$, the composite membranes exhibited lower methanol permeability than NF and NF117, with the lowest methanol permeability being obtained using MOR/NF composite membrane. This might be due to the homogeneous dispersion of MOR fillers in Nafion matrix that can block the passage of methanol through the Nafion membrane. The fact that NF had a lower methanol permeability than NF117 might be due to the difference in preparation method: prepared solvent, evaporation time, or fabrication apparatus. However, ANA/NF composite membrane exhibited higher methanol permeability than MOR/NF composite membrane both at low and high testing temperature. This might be due to the intrinsic properties of ANA and MOR. Furthermore, ANA has a larger pore diameter $(15.00 \AA)$ than MOR (5.16 ̊). Thus, more methanol can be adsorbed in the voids of ANA/NF than in than MOR/NF composite membrane, as previously mentioned when discussing methanol uptake [46]. MOR/NF composite membrane showed lower methanol permeability than ANA/NF at both testing temperatures. Thus, it can be concluded that MOR was a suitable filler for use in PEM or DMFC. 


\subsubsection{Selectivity}

Membranes for DMFC application are required to have high proton conductivity and low methanol permeability. In order to compare the applicability of a fabricated PEM, the selectivity is usually evaluated [15]. Figure 17 shows the selectivity of the composite membranes filled with ANA and MOR. It was observed that MOR/NF composite membrane showed the highest selectivity: $36.6 \times 10^{3}$ and $32.7 \times 10^{3} \mathrm{~S} \cdot \mathrm{s} \cdot \mathrm{cm}^{-3}$ at $30{ }^{\circ} \mathrm{C}$ and $70{ }^{\circ} \mathrm{C}$, respectively. This was mainly due to the small value of methanol permeability and high value of proton conductivity of this membrane. The results suggested that the MOR/NF composite membrane prepared by spray method should be suitable for DMFC application.

\subsubsection{Mechanical properties}

The mechanical properties of the PEMs are important for fuel cell applications. Many studies have indicated that mechanical failures of PEM due to the impacts of temperature, humidity, and force during the fuel cell operation can reduce the fuel cell life [47-49]. Tensile properties of all composite membranes are summarized in Table 4. It was found that the tensile strength of NF117 was 26.65 MPa, which was in good agreement with Lin's work [50], and it was found that the composite membranes had slightly lower tensile strength than those of NF and commercial membrane.

It was observed that all composite membranes have tensile strength slightly lower than those of NF and NF117, which may be due to the addition of inorganic particles causing the formation of rigid polymer chains and reduction in elongation [26]. Silane treated on the surface caused higher cross-linking between polymer chains and fillers, increased the stiffness (stiffness being the deformation resistance of the object responding to an applied force) of the membrane, and reduced its tensile strength [48]. ANA/NF had a slightly higher tensile strength (18.29 MPa) than MOR/NF (16.60 MPa): see Table 4. However, MOR/NF had a greater Young's modulus than ANA/NF, NF, and NF117. From this, it can be inferred that MOR/NF had a better resistance to the deformation under applied force than ANA/NF.

\subsubsection{DMFC performance}

DMFC tests were performed using composite membranes and compared with results for NF and NF117. Operation conditions were as follows: operating temperatures of 30, 50, and $70{ }^{\circ} \mathrm{C}$; a methanol flow rate of $5 \mathrm{ml} \cdot \mathrm{min}^{-1}$; and an air flow rate of $1 \mathrm{~L} \cdot \mathrm{min}^{-1}$. The voltage 
and power density of the composite membranes were found to be higher than those of NF and NF117. Normally, a low proton conductivity and a high methanol permeability contribute to poor DMFC performance. DMFC performance could thus be enhanced by improving proton conductivity and lower methanol permeability, which are represented in terms of selectivity, as mentioned in section 3.2.8. All composite membranes showed higher selectivity than those of NF and NF117 membranes.

Using a methanol concentration of 1bM (see Figure 18), all membranes showed similar performance, as could be observed from power density values. When increasing the methanol concentration to $2 \mathrm{M}$ and $4 \mathrm{M}$, the DMFC performance of MOR/NF composite membrane exhibited obviously greater power density than those of ANA/NF composite membrane, NF and NF117, as shown in Figure 19 and Figure 20. The higher DMFC performance of MOR/NF composite membrane was due to lower methanol permeability and higher proton conductivity or higher selectivity, relative to other membranes.

From Figures 18-20 show that when increasing the operation temperature from $30{ }^{\circ} \mathrm{C}$ to $50^{\circ} \mathrm{C}$, and then to $70^{\circ} \mathrm{C}$, the DMFC performance improved, can be observed from the higher (increased) power density. This was due to better transportation of proton through the membrane occurring at higher temperature [51]. Moreover, the gas diffusivity and membrane conductivity increase with increased operation temperature. Thus, using a higher temperature, the DMFC performance was enhanced. MOR/NF composite membrane showed higher DMFC performance than the other membranes, especially at $70^{\circ} \mathrm{C}[51]$.

MOR/NF composite membranes could resist methanol transport, resulting in lower methanol diffusion with increasing methanol concentration. Therefore, better DMFC performance was achieved when using methanol concentrations. This was consistent with Deluca's report in which the DMFC performance increased with increasing methanol feed concentration when membranes with a higher selectivity were used [52]. The highest power density of MOR/NF composite membrane was achieved at $70{ }^{\circ} \mathrm{C}$ and with $2 \mathrm{M}$ methanol: 10.75 $\mathrm{mW} \cdot \mathrm{cm}^{-2}$. The result was slightly lower with $4 \mathrm{M}$ methanol, this is, $10.64 \mathrm{~mW} \cdot \mathrm{cm}^{-2}$.

\section{Conclusions}

In this work, ANA/NF, MOR/NF, NF, and NF117 membranes for use in DMFC were characterized and compared. Spray method was used to prepare the membranes as it was 
expected to improve the homogeneous dispersion of filler particles in Nafion matrix and reduce the particle separation from the matrix which can be found in the composite membrane fabricated following a solution-casting method. The composite membranes with MOR filler gave better membrane properties than those using ANA filler. In particular, they had higher proton conductivity and lower methanol permeability, which reflected in the selectivity value. MOR/NF composite membrane had a selectivity about two and three times higher than that of ANA/NF composite membrane at 30 and $70{ }^{\circ} \mathrm{C}$, respectively. As regards use as DMFC, it was found that MOR/NF composite membranes showed the best performance. It was clearly seen that MOR/NF composite membrane showed excellent performance, especially at high temperature and high concentration, relative to the others. The maximum power density $(10.75$ $\mathrm{mW} \cdot \mathrm{cm}^{-2}$ ) was obtained with MOR/NF composite membrane using $2 \mathrm{M}$ methanol and at 70 ${ }^{\circ} \mathrm{C}$. Furthermore, MOR/NF composite membrane had a power density $2.1,1.4$, and 1.5 times higher than those of NF117, NF, and ANA/NF composite membrane, respectively. Therefore, the composite membrane with MOR filler prepared via spray method was promising for PEM to improve DMFC performance.

\section{Acknowledgements}

The authors would like to acknowledge the following: the King Mongkut's University of Technology North Bangkok for financial support (KMUTNB-NRU-58-18); the Kasetsart University Research and Development Institute (KURDI); the Faculty of Engineering, Kasetsart University; the Center for Advanced Studied in Nanotechnology, Applications in Chemical, Food and Agricultural Industries, Kasetsart University; the National Center of Excellence for Petroleum, Petrochemicals, and Advanced Materials. 


\section{References}

[1] A.S. Aricò, S. Srinivasan, V. Antonucci, DMFCs: From Fundamental Aspects to Technology Development, Fuel Cells, 1 (2001) 133-161.

[2] R. Dillon, S. Srinivasan, A.S. Aricò, V. Antonucci, International activities in DMFC R\&D: status of technologies and potential applications, Journal of Power Sources, 127 (2004) 112126.

[3] N. Nakagawa, Y. Xiu, Performance of a direct methanol fuel cell operated at atmospheric pressure, Journal of Power Sources 118 (2003) 248-255.

[4] A. Hacquard, Improving and understanding direct methanol fuel (DMFC) performance, in: Chemical Engineering, WORCESTER POLYTECHNIC INSTITUTE, 2005, pp. 107.

[5] C. Yoonoo, C.P. Dawson, E.P.L. Roberts, S.M. Holmes, Nafion®/mordenite composite membranes for improved direct methanol fuel cell performance, Journal of Membrane Science, 369 (2011) 367-374.

[6] Z. Zhang, F. Désilets, V. Felice, B. Mecheri, S. Licoccia, A.C. Tavares, On the proton conductivity of Nafion-Faujasite composite membranes for low temperature direct methanol fuel cells, Journal of Power Sources, 196 (2011) 9176-9187.

[7] A. Heinzel, V.M. Barragán, A review of the state-of-the-art of the methanol crossover in direct methanol fuel cells, Journal of Power Sources, 84 (1999) 70-74.

[8] X. Li, E.P.L. Roberts, S.M. Holmes, V. Zholobenko, Functionalized zeolite A-Nafion composite membranes for direct methanol fuel cells, Solid State Ionics, 178 (2007) 1248-1255. [9] V. Gogel, T. Frey, Z. Yongsheng, K.A. Friedrich, L. Jörissen, J. Garche, Performance and methanol permeation of direct methanol fuel cells: dependence on operating conditions and on electrode structure, Journal of Power Sources, 127 (2004) 172-180.

[10] L. Gubler, M. Slaski, A. Wokaun, G.G. Scherer, Advanced monomer combinations for radiation grafted fuel cell membranes, Electrochemistry Communications, 8 (2006) 1215-1219. [11] J.G. Liu, T.S. Zhao, Z.X. Liang, R. Chen, Effect of membrane thickness on the performance and efficiency of passive direct methanol fuel cells, Journal of Power Sources, 153 (2006) 61-67.

[12] V. Baglio, A.S. Arico, A.D. Blasi, P.L. Antonucci, F. Nannetti, V. Tricoli, V. Antonucci, Zeolite-based composite membranes for high temperature direct methanol fuel cells, Journal of Applied Electrochemistry, 35 (2005) 207-212. 
[13] J. Ahmad, M.B. Hägg, Effect of zeolite preheat treatment and membrane post heat treatment on the performance of polyvinyl acetate/zeolite $4 \mathrm{~A}$ mixed matrix membrane, Separation and Purification Technology, 115 (2013) 163-171.

[14] M.H. Yildirim, A.R. Curòs, J. Motuzas, A. Julbe, D.F. Stamatialis, M. Wessling, Nafion $® / H-Z S M-5$ composite membranes with superior performance for direct methanol fuel cells, Journal of Membrane Science, 338 (2009) 75-83.

[15] H. Wu, B. Zheng, X. Zheng, J. Wang, W. Yuan, Z. Jiang, Surface-modified Y zeolitefilled chitosan membrane for direct methanol fuel cell, Journal of Power Sources, 173 (2007) $842-852$.

[16] E.N. Gribov, E.V. Parkhomchuk, I.M. Krivobokov, J.A. Darr, A.G. Okunev, Supercritical $\mathrm{CO} 2$ assisted synthesis of highly selective nafion-zeolite nanocomposite membranes for direct methanol fuel cells, Journal of Membrane Science, 297 (2007) 1-4.

[17] M. Rikukawa, K. Sanui, Proton-conducting polymer electrolyte membranes based on hydrocarbon polymers, Progress in Polymer Science, 25 (2000) 1463-1502.

[18] B. Libby, W.H. Smyrl, E.L. Cussler, Polymer-zeolite composite membranes for direct methanol fuel cells, AIChE Journal, 49 (2003) 991-1001.

[19] S.H. Kwak, T.H. Yang, C.S. Kim, K.H. Yoon, Nafion/mordenite hybrid membrane for high-temperature operation of polymer electrolyte membrane fuel cell, Solid State Ionics, 160 (2003) 309-315.

[20] N. Intaraprasit, P. Kongkachuichay, Preparation and properties of sulfonated poly(ether ether ketone)/Analcime composite membrane for a proton exchange membrane fuel cell (PEMFC), Journal of the Taiwan Institute of Chemical Engineers, 42 (2011) 190-195.

[21] P. Kongkachuichay, S. Pimprom, Nafion/Analcime and Nafion/Faujasite composite membranes for polymer electrolyte membrane fuel cells, Chemical Engineering Research and Design, 88 (2010) 496-500.

[22] A. Corma, C. Corell, J. Perez-Pariente, synthesis and characterization of the mcm-22, Zeolites, 15 (1995) 2-8.

[23] G.J. Kim, W.S. Ahn, Direct synthesis and characterization of high-SiO2-content mordenites, Zeolites, 11 (1991) 745-750.

[24] M.A. Zanjanchi, S. Sohrabnezhad, Evaluation of methylene blue incorporated in zeolite for construction of an optical humidity sensor, Sensors and Actuators B: Chemical, 105 (2005) 502-507.

[25] M.A. Zanjanchi, S. Sohrabnejad, Intercalation of Methylene Blue into Mordenites: Role of Zeolite Acidity, Journal of Inclusion Phenomena, 46 (2003) 43-49. 
[26] Y.M. Sun, W.F. Huang, C.C. Chang, Spray-coated and solution cast ethylcellulose pseudolatex membranes, Journal of Membrane Science 157 (1999) 159-170.

[27] P. Prapainainar, A. Theampetch, P. Kongkachuichay, N. Laosiripojana, S.M. Holmes, C. Prapainainar, Effect of solution casting temperature on properties of nafion composite membrane with surface modified mordenite for direct methanol fuel cell, Surface and Coatings Technology, (2015).

[28] R.B. Moore, C.R. Martin, chemical and morphological properties of solution cast perfluorosulfonate ionomers, Macromelecules, 21 (1988) 1334-1339.

[29] A. Theampetch, Solution Casting And Modification Of Surface Filler In Nafion Modenite Composire Membrane For Direct Alcohol Fuel Cell in: Chemical Engineering, King Mongkut's University of Technology North Bangkok, 2014.

[30] H.M. Aly, M.E. Moustafa, E.A. Abdelrahman, Synthesis of mordenite zeolite in absence of organic template, Advanced Powder Technology, 23 (2012) 757-760.

[31] W.M. Meier, D. Olson, D.H. Olson, I.Z.A.S. Commission, Atlas of zeolite structure types, Structure Commission of the International Zeolite Association, 1978.

[32] P. Sharma, P. Rajaram, R. Tomar, Synthesis and morphological studies of nanocrystalline MOR type zeolite material, Journal of Colloid and Interface Science, 325 (2008) 547-557.

[33] B.O. Hincapie, L.J. Garces, Q. Zhang, A. Sacco, S.L. Suib, Synthesis of mordenite nanocrystals, Microporous and Mesoporous Materials, 67 (2004) 19-26.

[34] C.R. Tanardi, A.F.M. Pinheiro, A. Nijmeijer, L. Winnubst, PDMS grafting of mesoporous $\gamma$-alumina membranes for nanofiltration of organic solvents, Journal of Membrane Science, 469 (2014) 471-477.

[35] S.N. Azizi, A. Alavi Daghigh, M. Abrishamkar, Phase Transformation of Zeolite P to Y and Analcime Zeolites due to Changing the Time and Temperature, Journal of Spectroscopy, 2013 (2013) 1-5.

[36] G.S. Ahmed, M. Gilbert, S. Mainprize, M. Rogerson, FTIR analysis of silane grafted high density ethylene, Plastics, Rubber and Composites, 38 (2009) 13-20.

[37] S. Ren, G. Sun, C. Li, Z. Liang, Z. Wu, W. Jin, X. Qin, X. Yang, Organic silica/Nafion® composite membrane for direct methanol fuel cells, Journal of Membrane Science, 282 (2006) $450-455$.

[38] Y. Kim, Y. Choi, H.K. Kim, J.S. Lee, New sulfonic acid moiety grafted on montmorillonite as filler of organic-inorganic composite membrane for non-humidified proton-exchange membrane fuel cells, Journal of Power Sources, 195 (2010) 4653-4659. 
[39] J. Xu, H. Ni, S. Wang, Z. Wang, H. Zhang, Direct polymerization of a novel sulfonated poly(arylene ether ketone sulfone)/sulfonated poly(vinylalcohol) crosslinked membrane for direct methanol fuel cell applications, Journal of Membrane Science, 492 (2015) 505-517.

[40] B. Zhang, Y. Cao, S. Jiang, Z. Li, G. He, H. Wu, Enhanced proton conductivity of Nafion nanohybrid membrane incorporated with phosphonic acid functionalized graphene oxide at elevated temperature and low humidity, Journal of Membrane Science, 518 (2016) 243-253.

[41] N. Shrotia, L. Barborab, A. Verma, Neodymium triflate modified nafion composite membrane for reduced alcohol permeability in direct alcohol fuel cell, International Journal of Hydrogen Energy, 36 (2011) 14907-14913.

[42] P. Chen, L. Hao, W. Wu, Y. Li, J. Wang, Polymer-inorganic hybrid proton conductive membranes: Effect of the interfacial transfer pathways, Electrochimica Acta, 212 (2016) 426439.

[43] Y. Park, Y. Yamazaki, Low water uptake content and low water/methanol transport in $\mathrm{CP} /$ Nafion hybrid membrane with high non-hydrogen bonding, Journal of Membrane Science, 261 (2005) 58-66.

[44] T. Sancho, J. Lemus, M. Urbiztondo, J. Soler, M.P. Pina, Zeolites and zeotype materials as efficient barriers for methanol cross-over in DMFCs, Microporous and Mesoporous Materials, 115 (2008) 206-213.

[45] D.-J. Kim, H.-Y. Hwang, S.-b. Jung, S.-Y. Nam, Sulfonated poly(arylene ether sulfone)/Laponite-SO3H composite membrane for direct methanol fuel cell, Journal of Industrial and Engineering Chemistry, 18 (2012) 556-562.

[46] J. Wang, X. Zheng, H. Wu, B. Zheng, Z. Jiang, X. Hao, B. Wang, Effect of zeolites on chitosan/zeolite hybrid membranes for direct methanol fuel cell, Journal of Power Sources, 178 (2008) 9-19.

[47] D. Xing, G. He, Z. Hou, P. Ming, S. Song, Properties and morphology of Nafion/polytetrafluoroethylene composite membrane fabricated by a solution-spray process, International Journal of Hydrogen Energy, 38 (2013) 8400-8408.

[48] N. Shroti, L. Barbora, A. Verma, Neodymium triflate modified nafion composite membrane for reduced alcohol permeability in direct alcohol fuel cell, International Journal of Hydrogen Energy, 36 (2011) 14907-14913.

[49] Y. Jin, S. Qiao, L. Zhang, Z.P. Xu, S. Smart, J.C.D.d. Costa, G.Q. Lu, Novel Nafion composite membranes with mesoporous silica nanospheres as inorganic fillers, Journal of Power Sources, 185 (2008) 664-669. 
[50] H. Lin, C. Zhao, Y. Jiang, W. Ma, H. Na, Novel hybrid polymer electrolyte membranes with high proton conductivity prepared by a silane-crosslinking technique for direct methanol fuel cells, Journal of Power Sources, 196 (2011) 1744-1749.

[51] Y. Devrim, A. Albostan, Enhancement of PEM fuel cell performance at higher temperatures and lower humidities by high performance membrane electrode assembly based on Nafion/zeolite membrane, International Journal of Hydrogen Energy, (2015).

[52] N.W. DeLuca, Y.A. Elabd, Direct methanol fuel cell performance of Nafion®/poly(vinyl alcohol) blend membranes, Journal of Power Sources, 163 (2006) 386-391. 

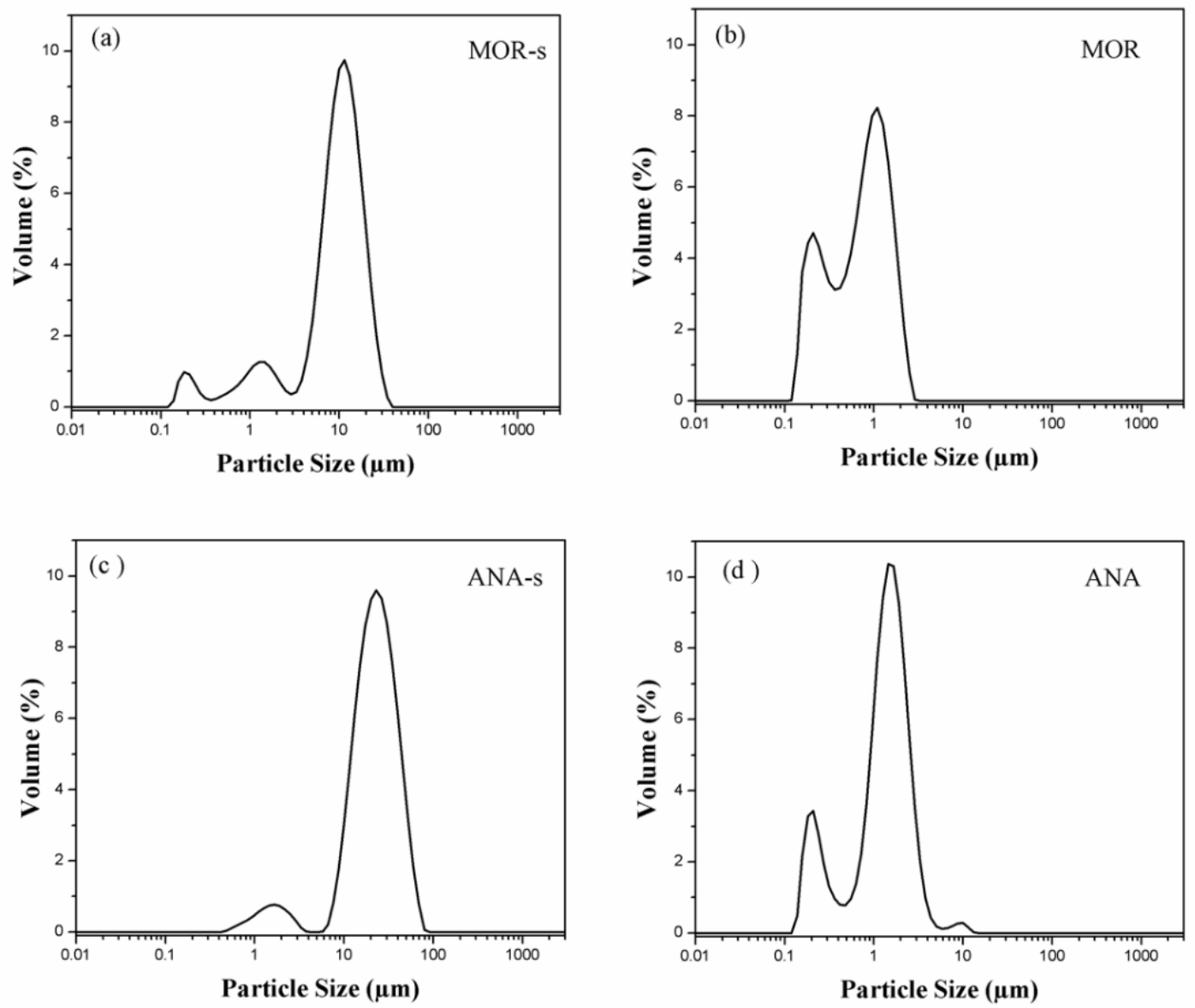

Figure 1 The particle size distributions of (a) MOR-s, (b) MOR, (c) ANA-s, and (d) ANA. 

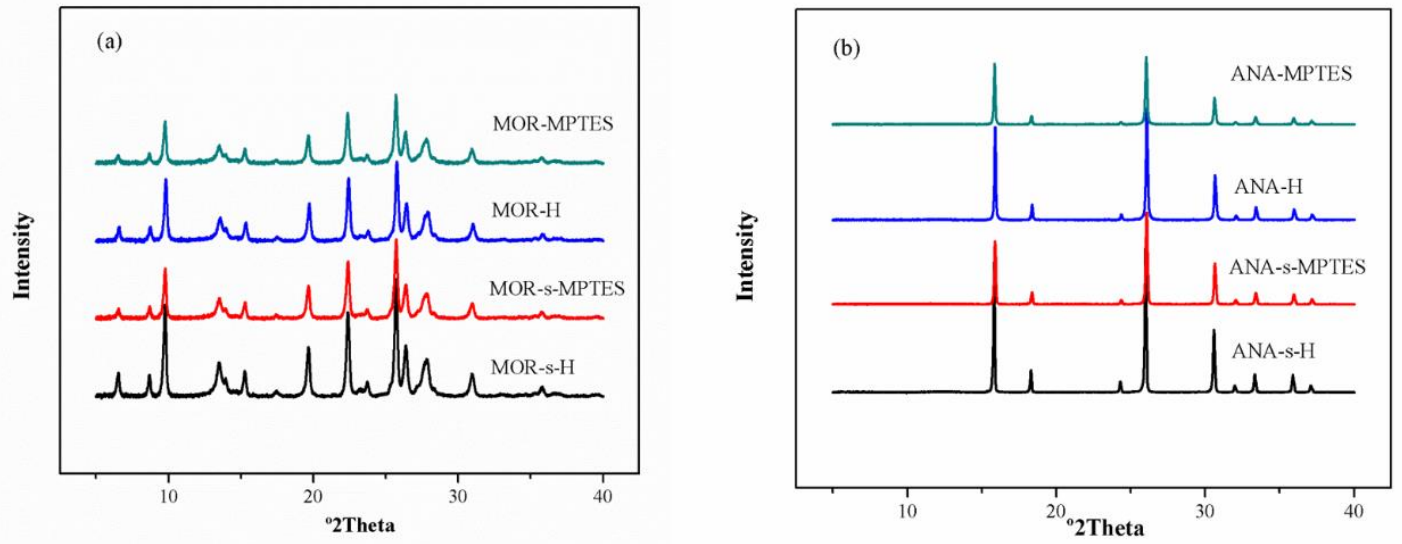

Figure 2 Comparison of XRD diffraction patterns of (a) MOR and (b) ANA at various conditions.
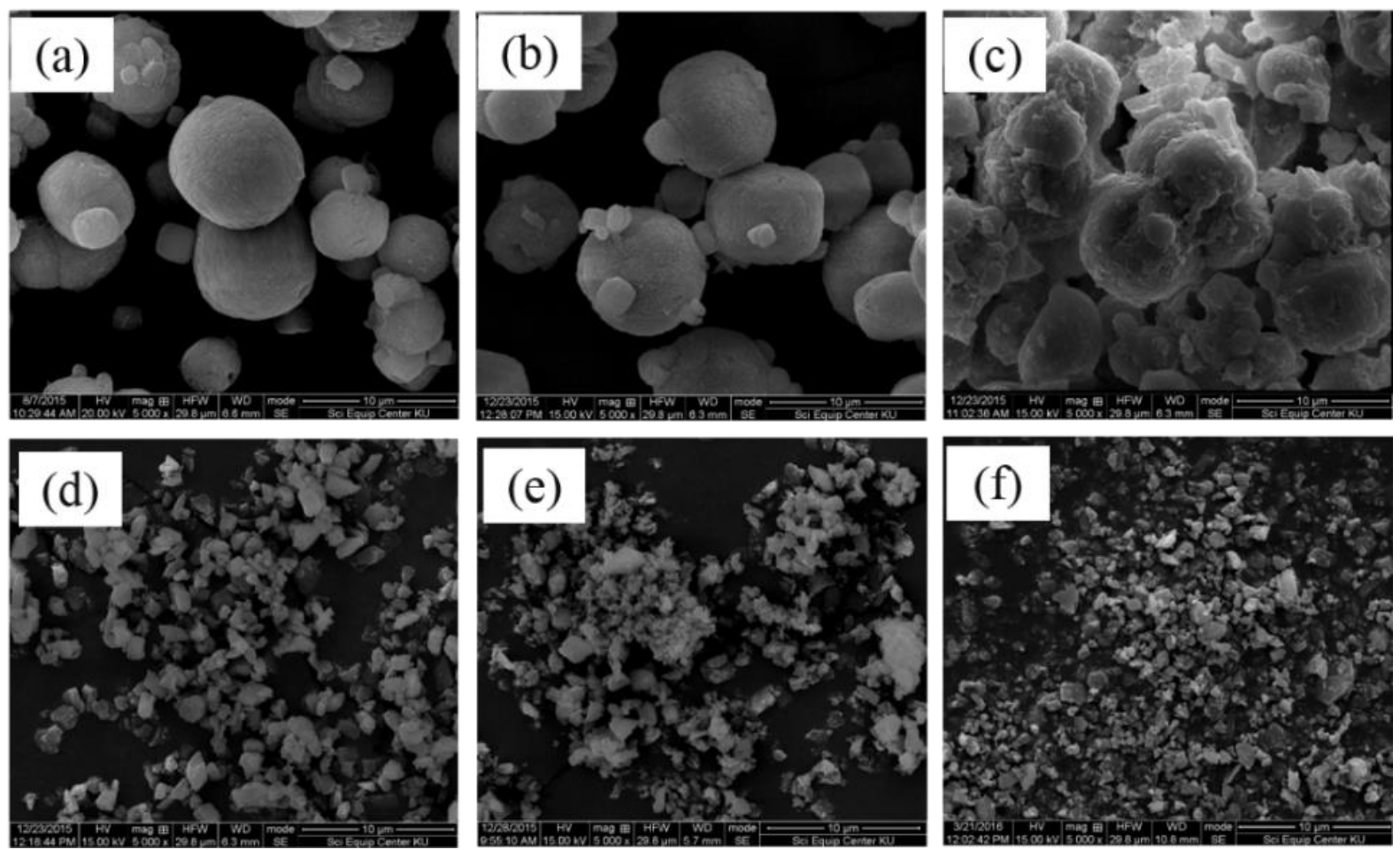

Figure 3 SEM images at 5000x magnification: (a) MOR-s, (b) MOR-s-H, (c) MOR-s-MPTES, (d) MOR, (e) MOR-H and (f) MOR-MPTES. 

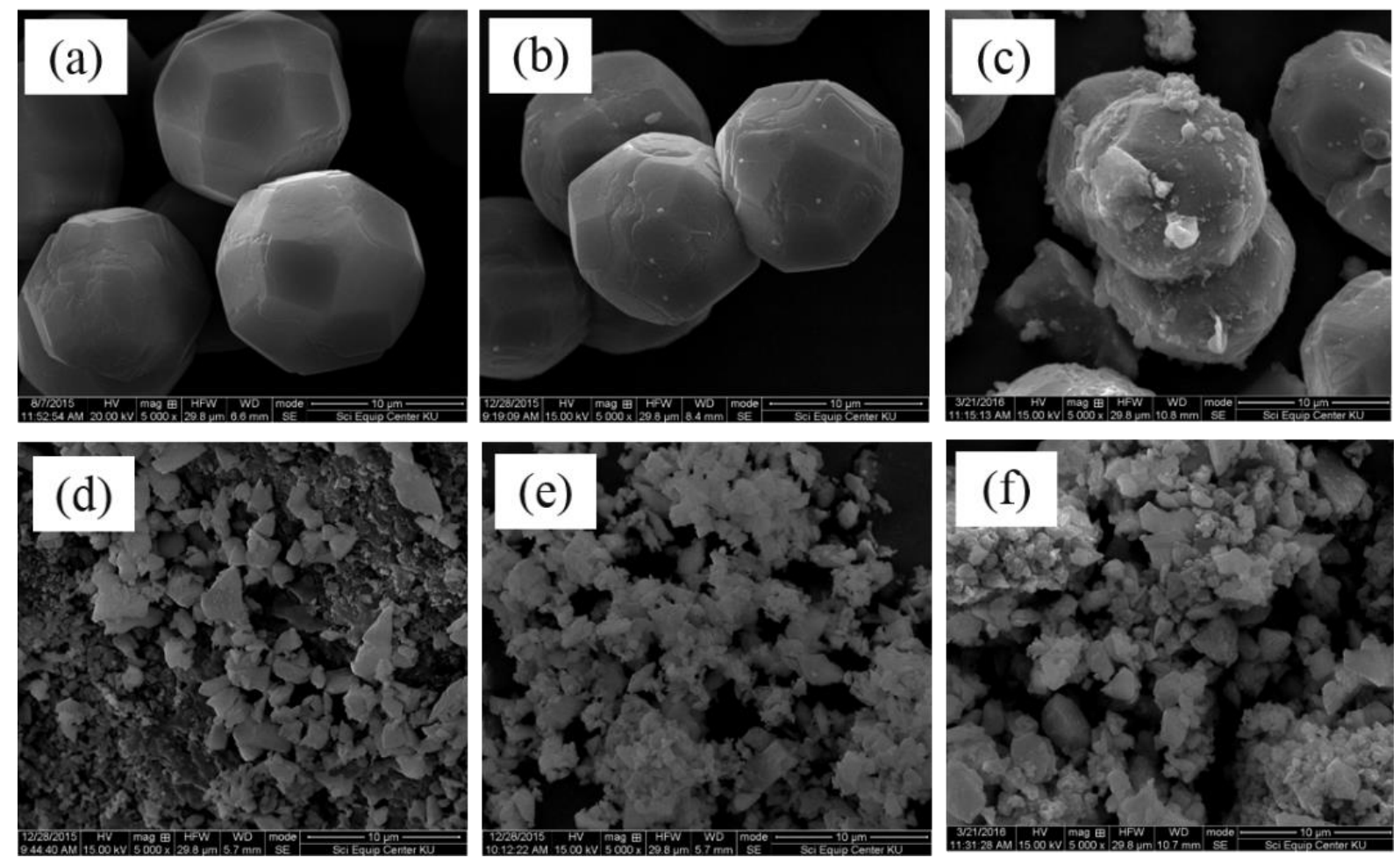

Figure 4 SEM images at 5000x magnification: (a) ANA-s, (b) ANA-s-H, (c) ANA-s-MPTES, (d) ANA, (e) ANA-H, and (f) ANA-MPTES. 

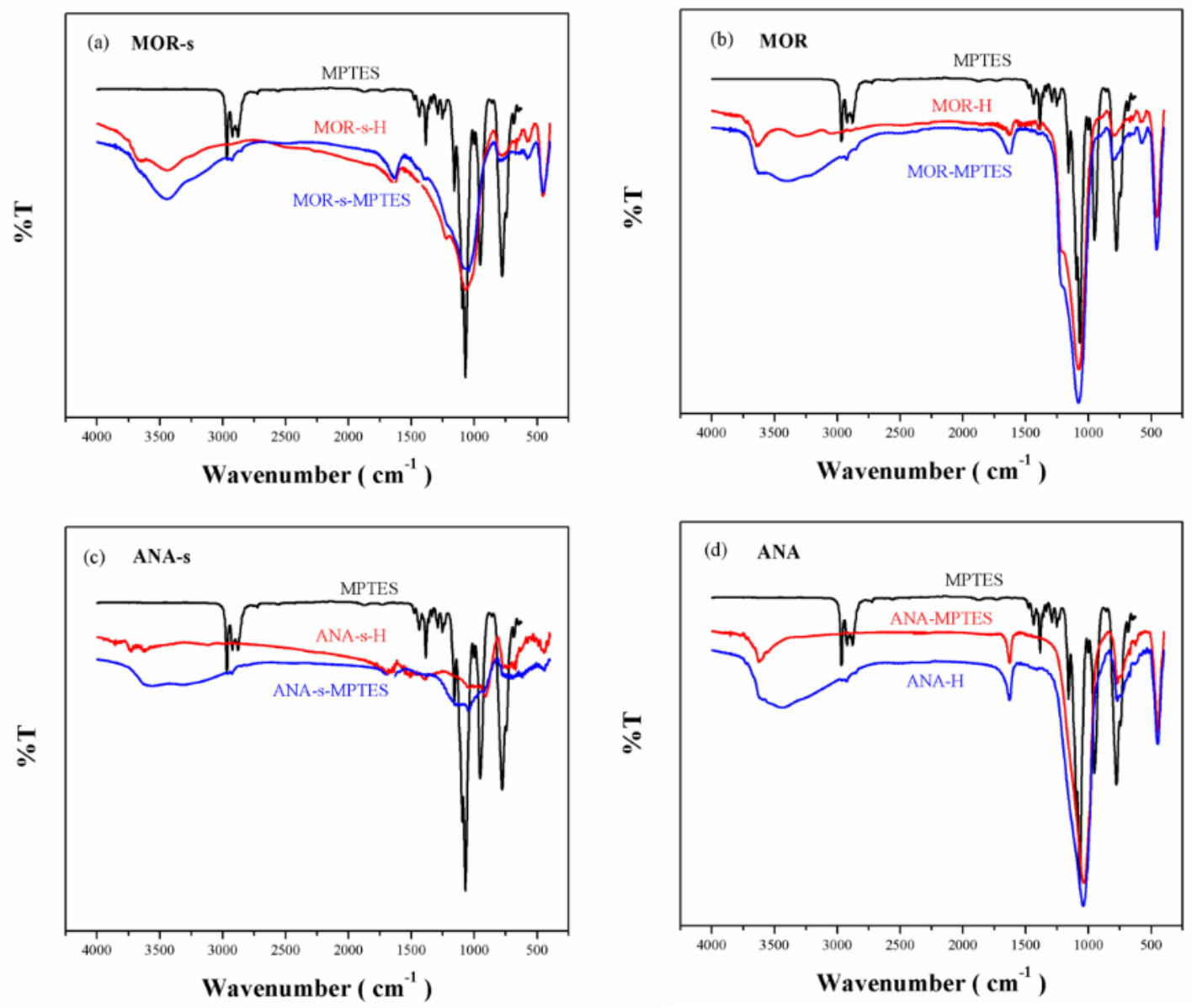

Figure 5 FTIR spectra of MOR and ANA before and after MPTES modification: (a) MOR-s, (b) MOR, (c) ANA-s, and (d) ANA. 

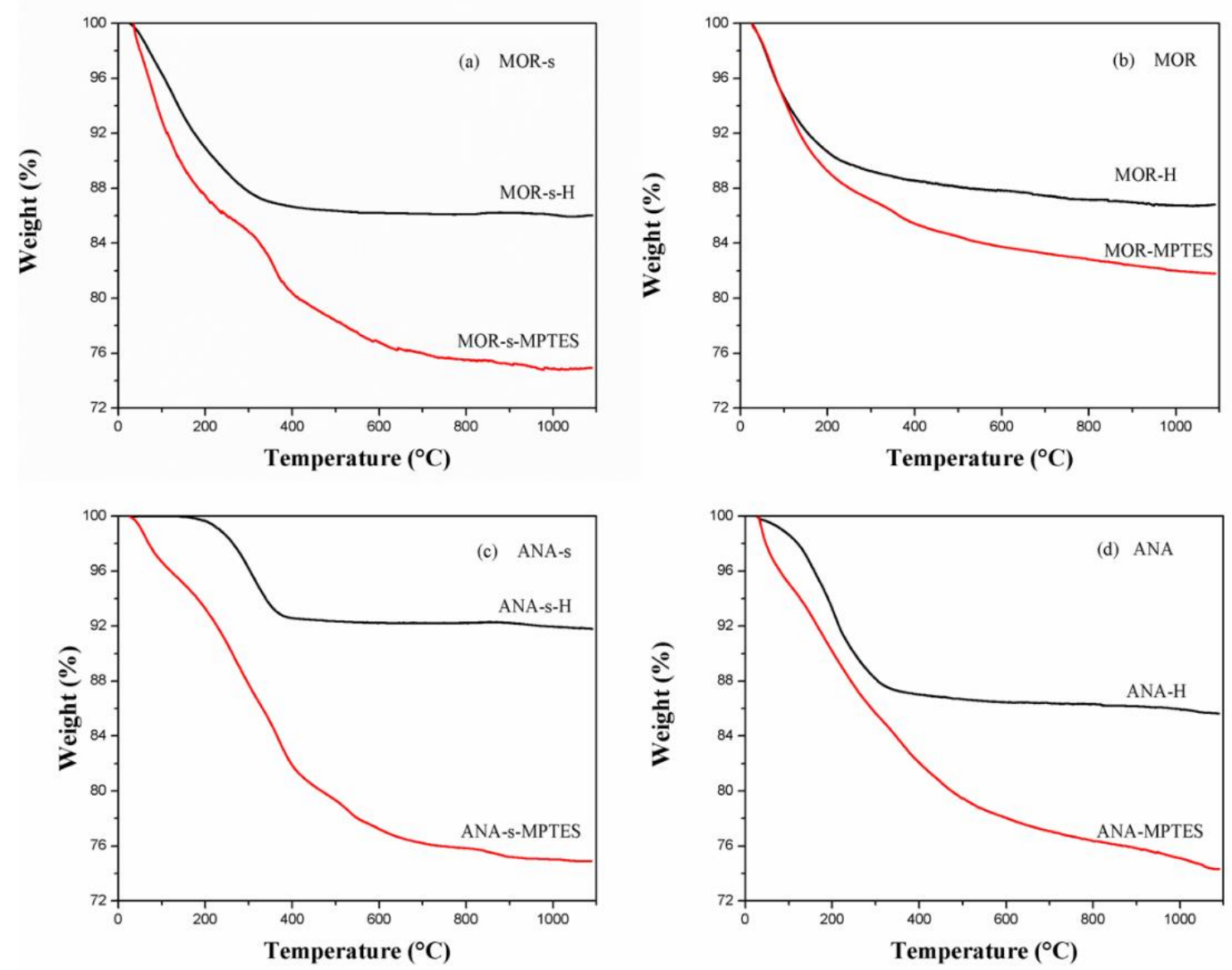

Figure 6 TGA diagrams of MOR and ANA before and after MPTES modification: (a) MOR-s, (b) MOR, (c) ANA-s, and (d) ANA. 

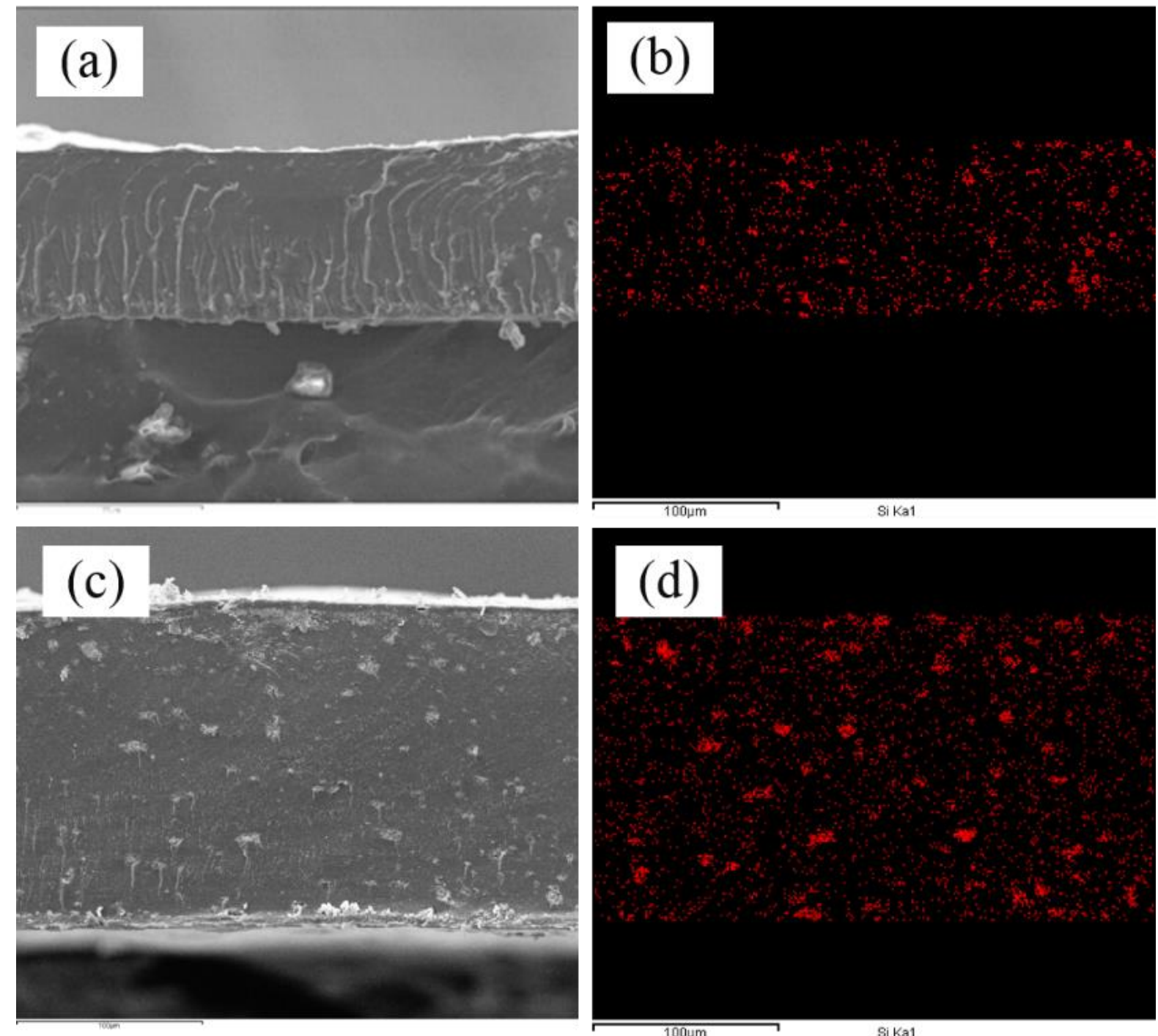

Figure 7 SEM/EDS images of composite membranes prepared using spray method: (a) crosssection of ANA/NF, (b) Si mapping of ANA/NF, (c) cross-section of MOR/NF, and (d) Si mapping of MOR/NF. 

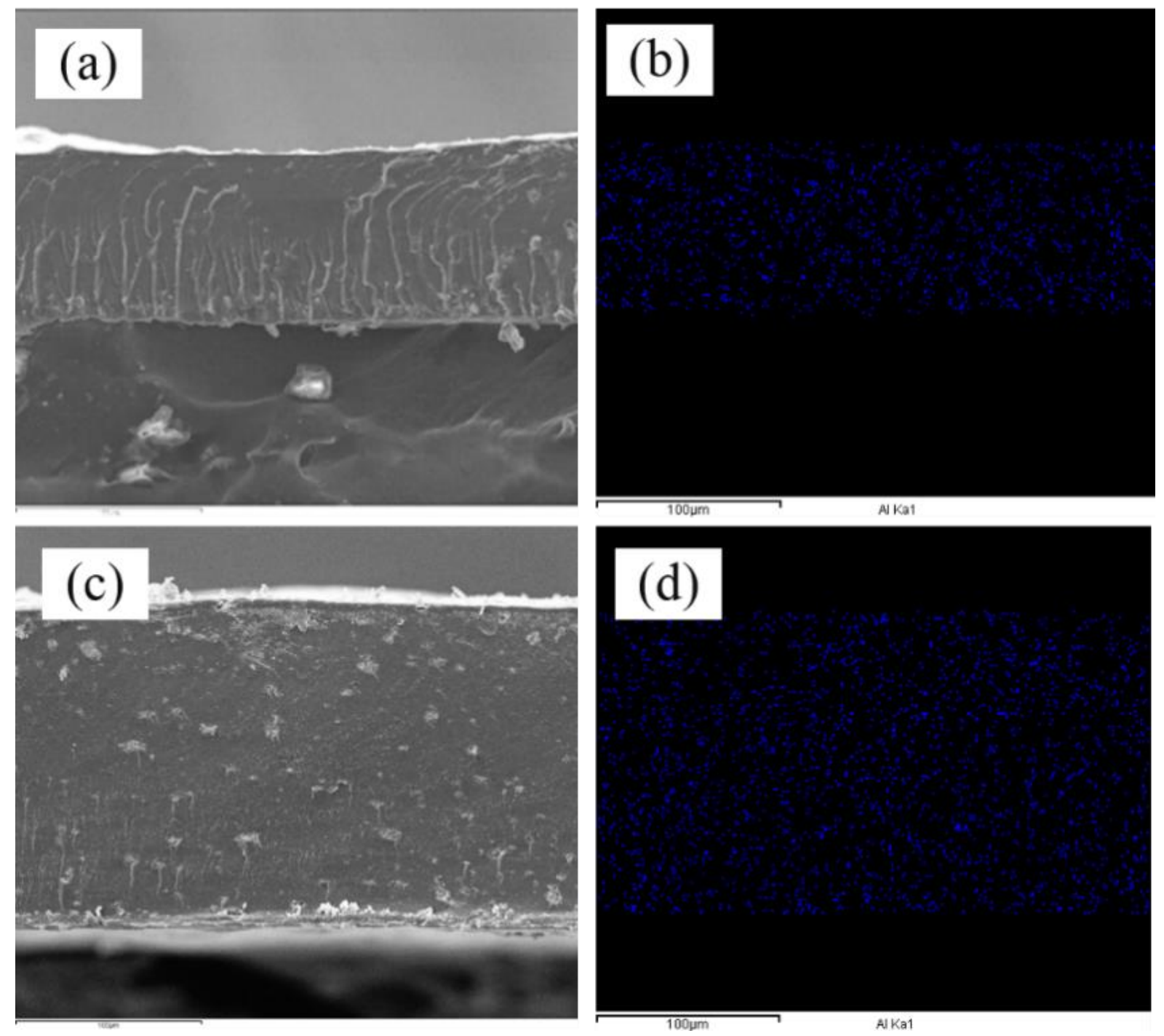

Figure 8 SEM/EDS images of composite membranes prepared using spray method: (a) crosssection of ANA/NF, (b) Al mapping of ANA/NF, (c) cross-section of MOR/NF, and (d) Al mapping of MOR/NF. 

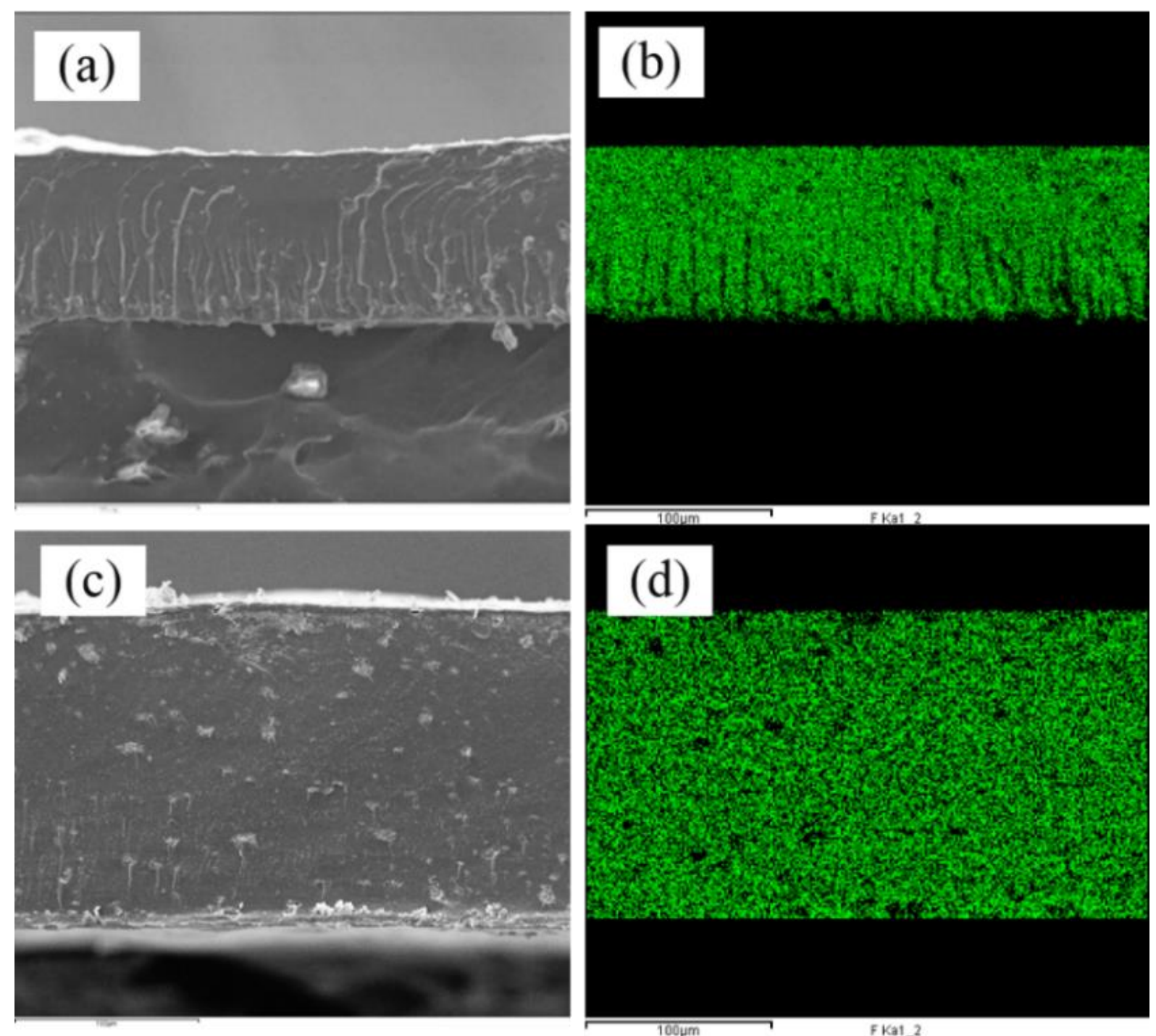

Figure 9 SEM/EDS images of composite membranes prepared using spray method: (a) crosssection of ANA/NF, (b) F mapping of ANA/NF, (c) cross-section of MOR/NF, and (d) F mapping of MOR/NF. 

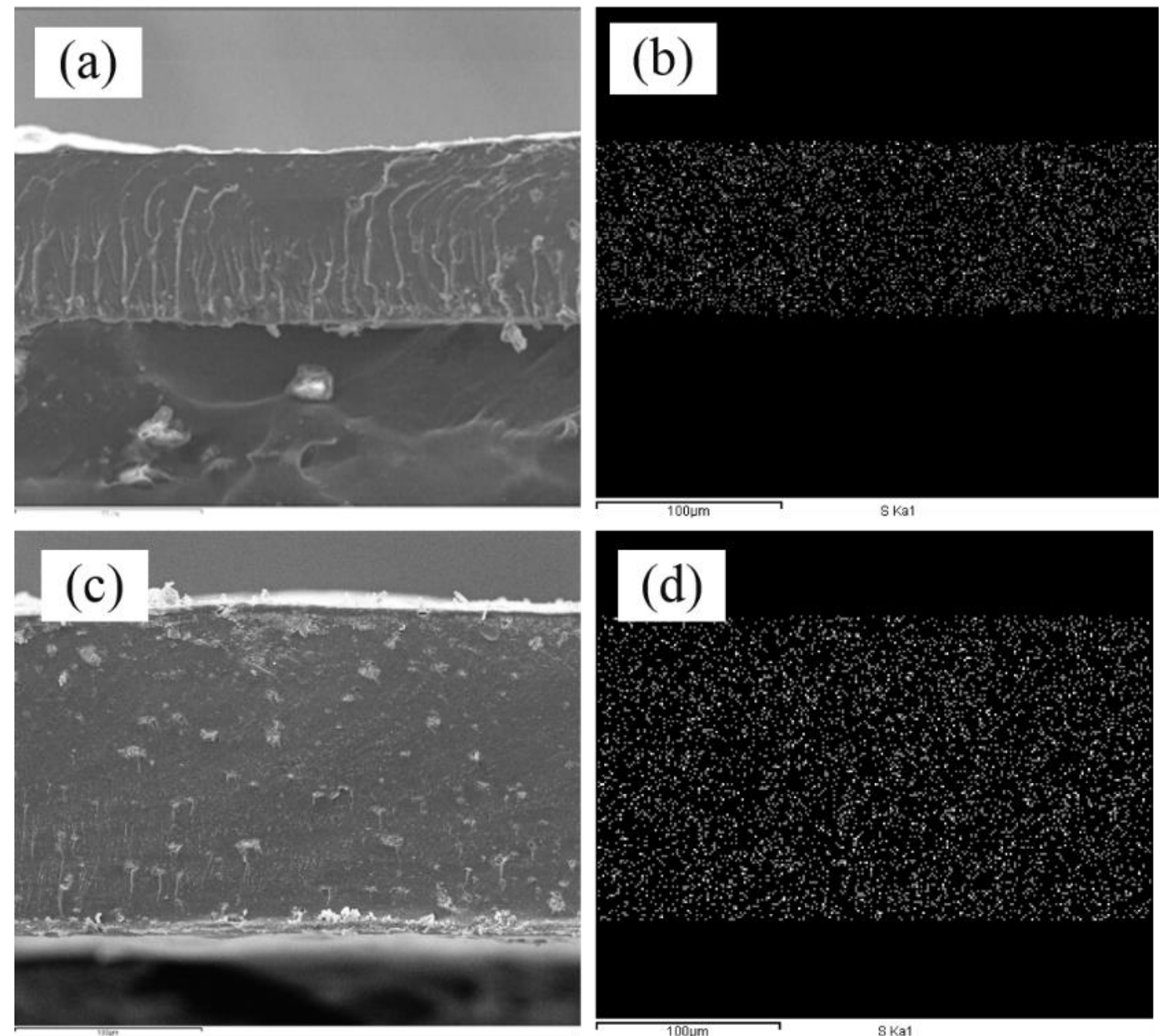

Figure 10 SEM/EDS images of composite membrane prepared using spray method: (a) crosssection of ANA/NF, (b) S mapping of ANA/NF, (c) cross-section of MOR/NF, and (d) S mapping of MOR/NF. 


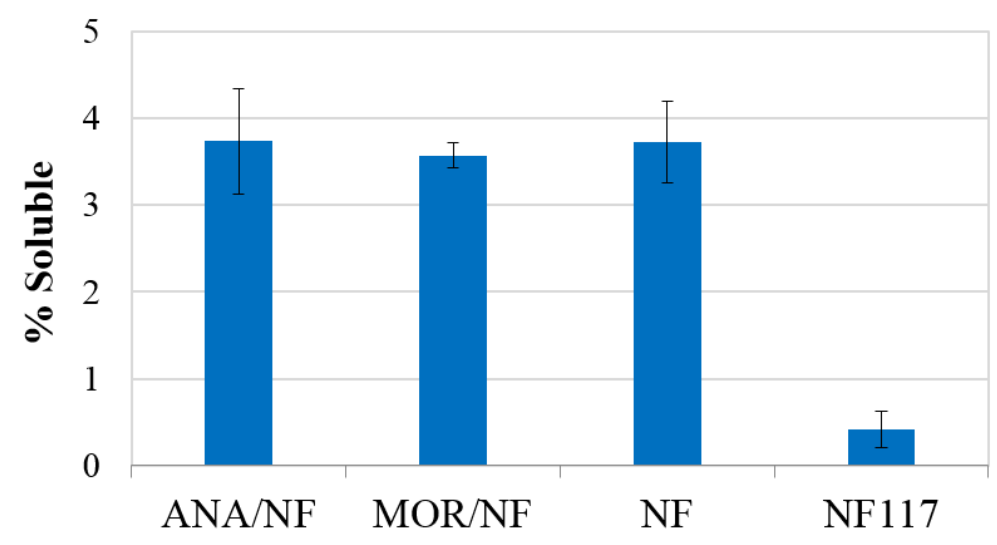

Figure 11 Solubility of all membranes prepared from spray method.

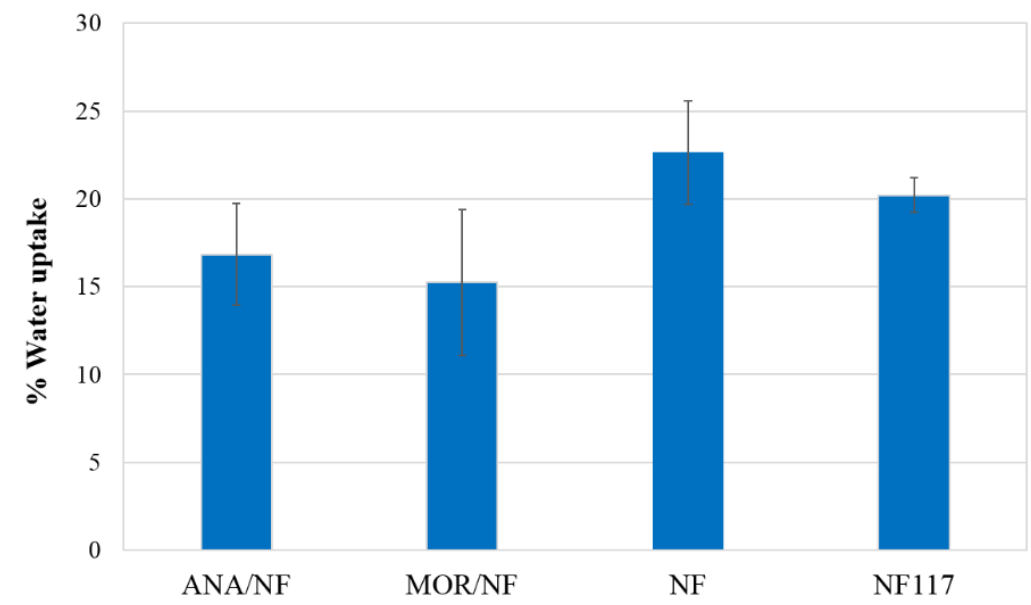

Figure 12 Water uptake of all membranes prepared via spray method. 


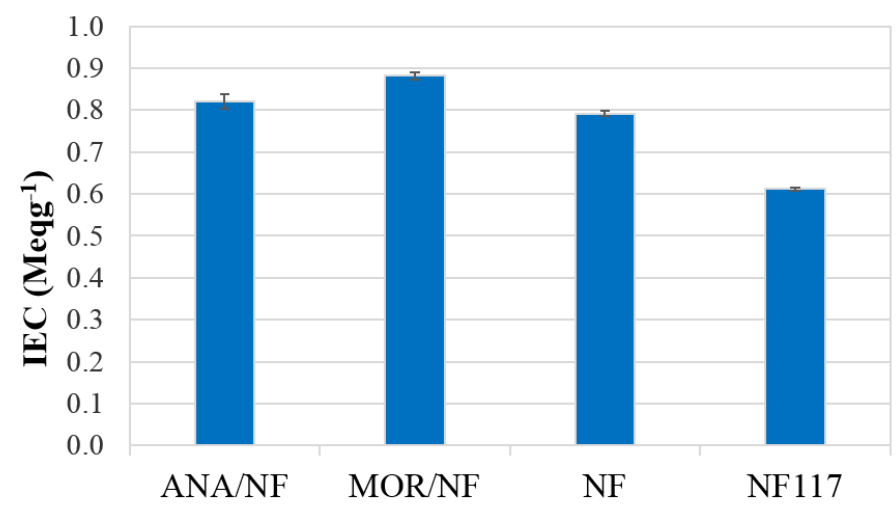

Figure 13 IEC of all membranes.

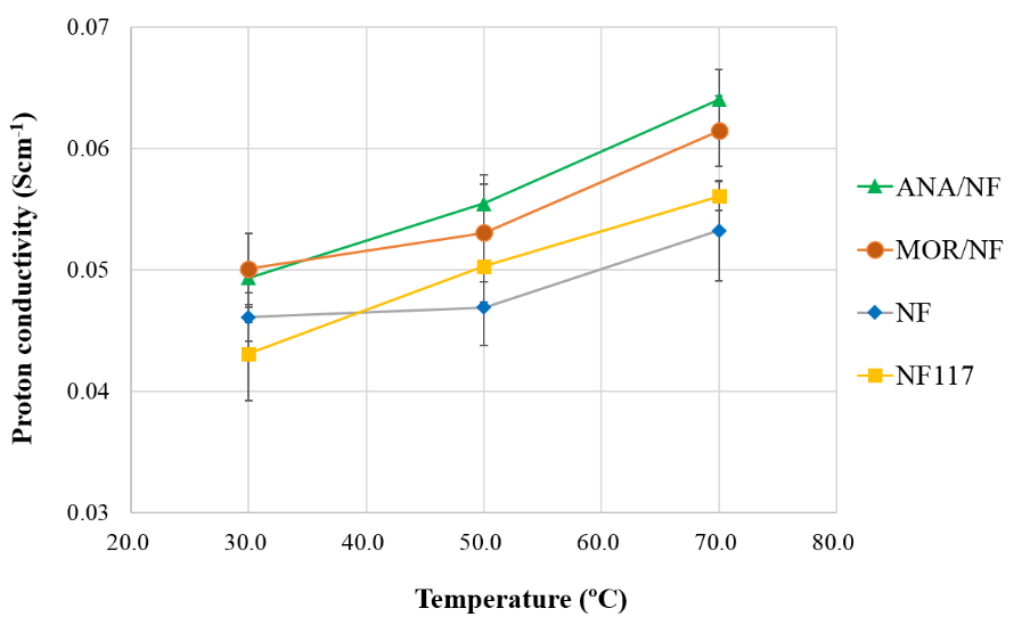

Figure 14 Proton conductivity of all membranes tested at 30,50 , and $70{ }^{\circ} \mathrm{C}$. 


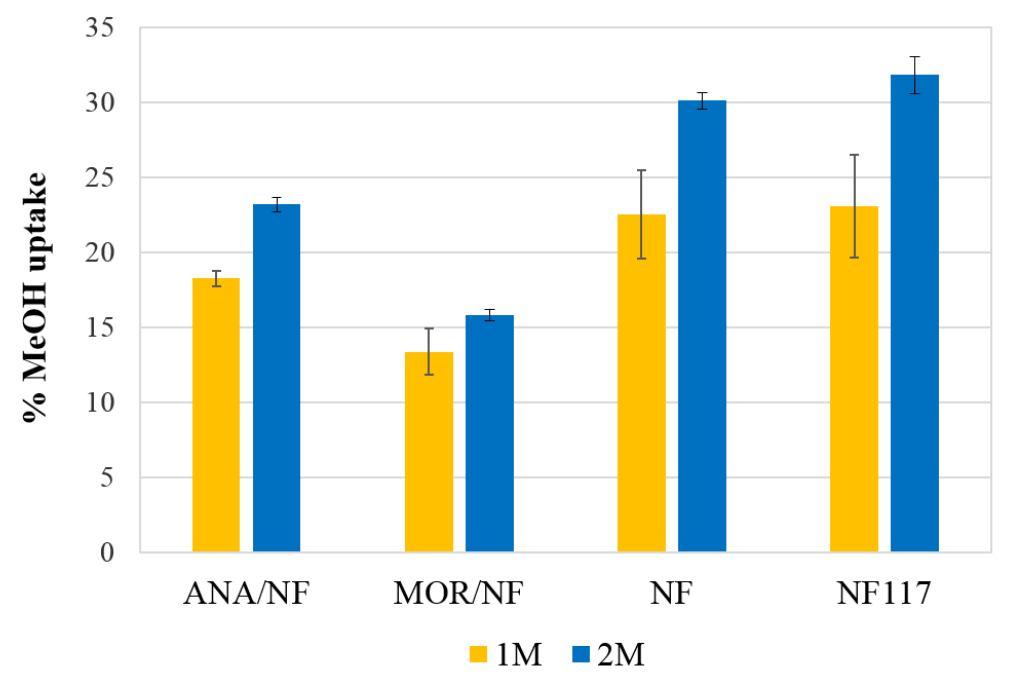

Figure 15 Methanol uptake of all membranes using methanol concentration of $1 \mathrm{M}$ and $2 \mathrm{M}$.

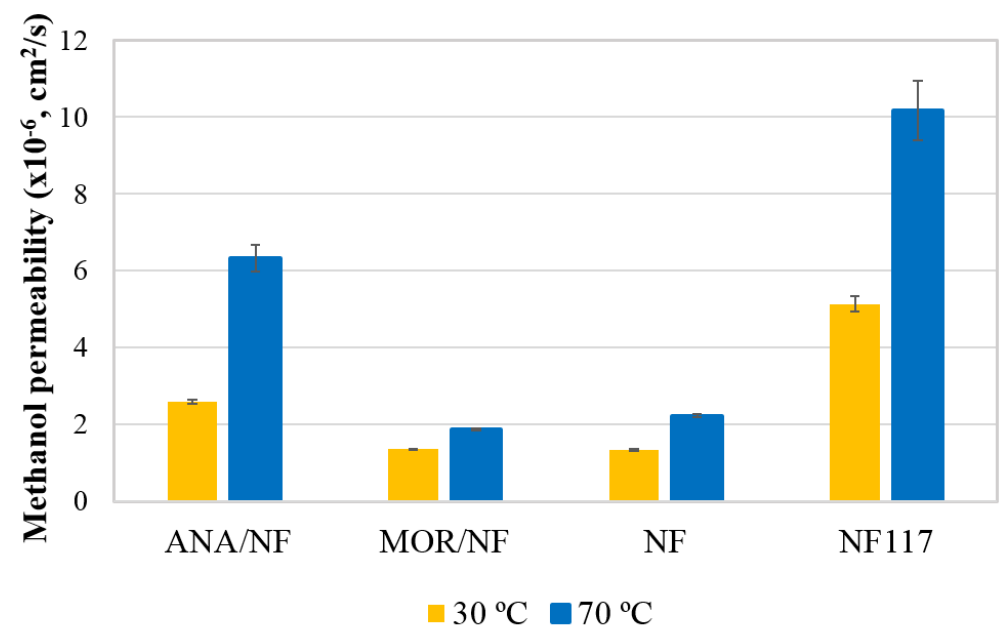

Figure 16 Methanol permeability of all membranes at testing temperature of $30{ }^{\circ} \mathrm{C}$ and $70{ }^{\circ} \mathrm{C}$. 


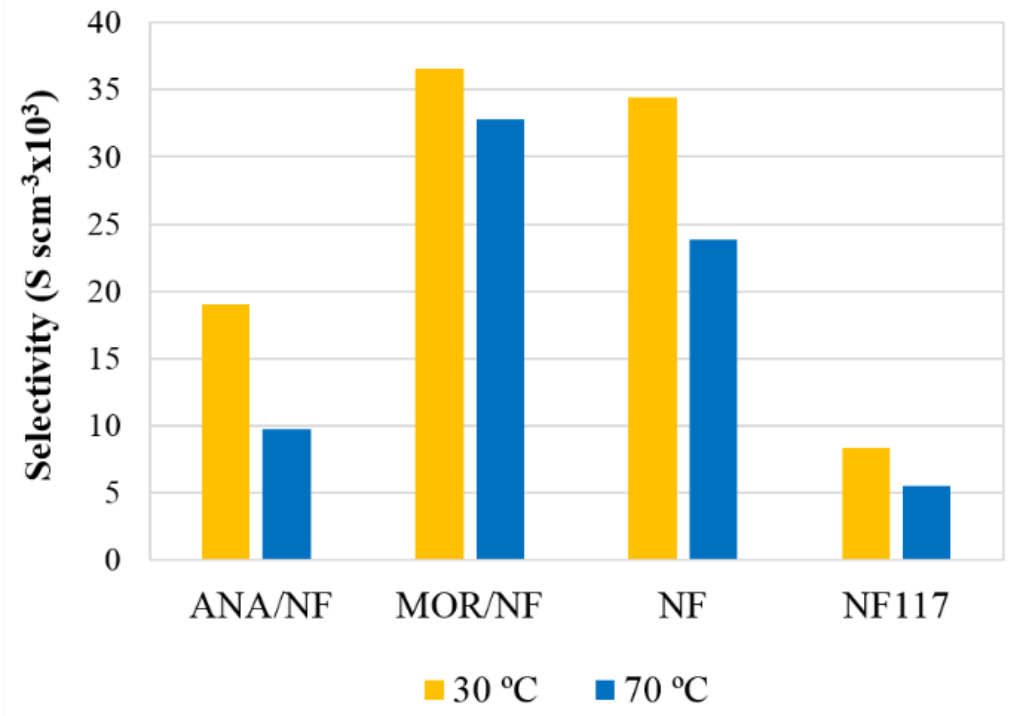

Figure 17 Selectivity of composite membranes prepared by spray method at testing temperature of $30^{\circ} \mathrm{C}$ and $70{ }^{\circ} \mathrm{C}$. 

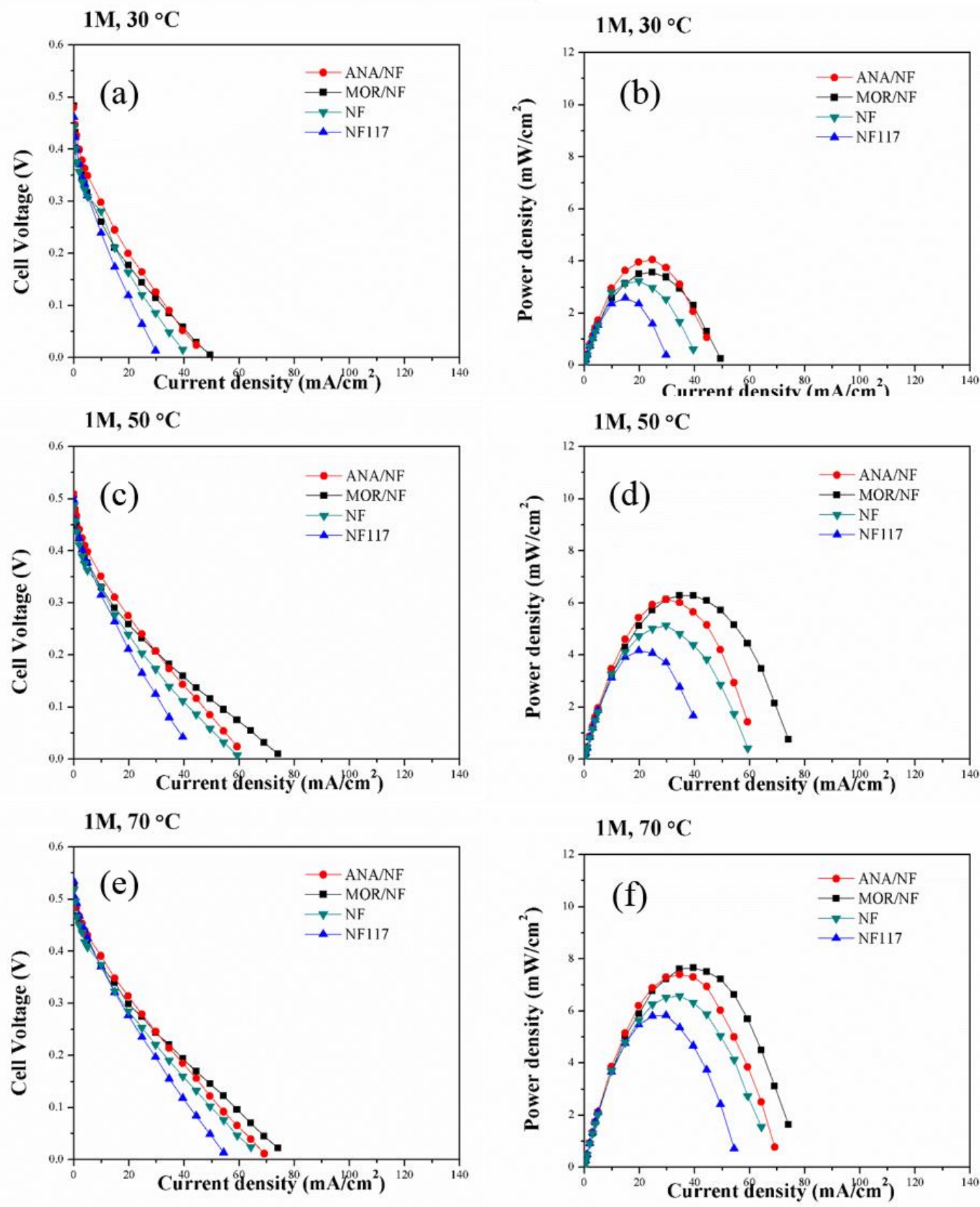

Figure 18 Polarization and power density curves highlighting the effect of preparation method of MOR/NF, ANA/NF, NF, NF117 on DMFC performance using $1 \mathrm{M}$ methanol: (a) - (b) $30{ }^{\circ} \mathrm{C}$, (c) - (d) $50{ }^{\circ} \mathrm{C}$, and (e) - (f) $70{ }^{\circ} \mathrm{C}$. 

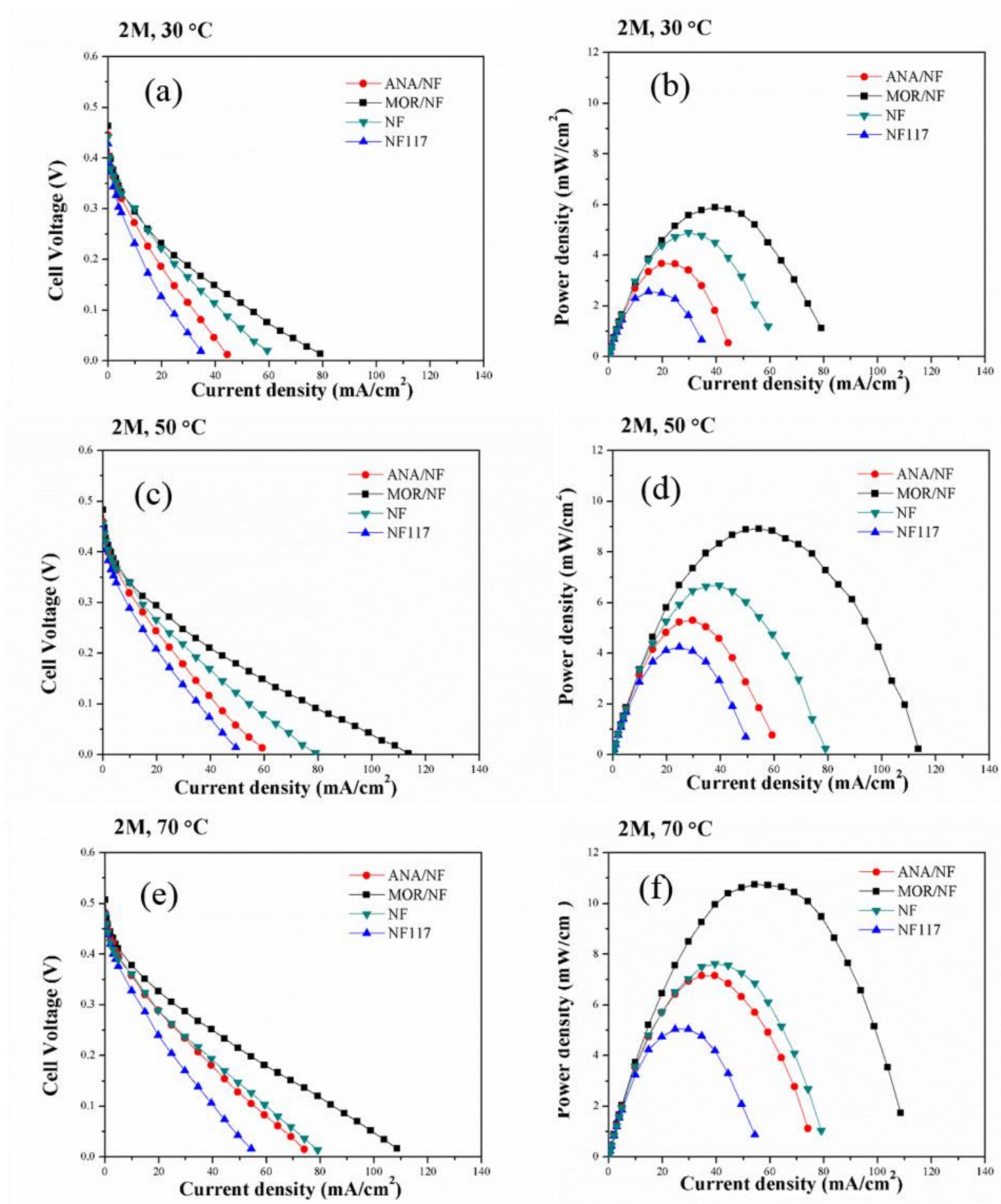

Figure 19 Polarization and power density curves highlighting the effect of preparation method of MOR/NF, ANA/NF, NF, NF117 on DMFC performance using 2 M methanol: (a) - (b) $30{ }^{\circ} \mathrm{C}$, (c) - (d) $50{ }^{\circ} \mathrm{C}$, and (e) - (f) $70{ }^{\circ} \mathrm{C}$. 

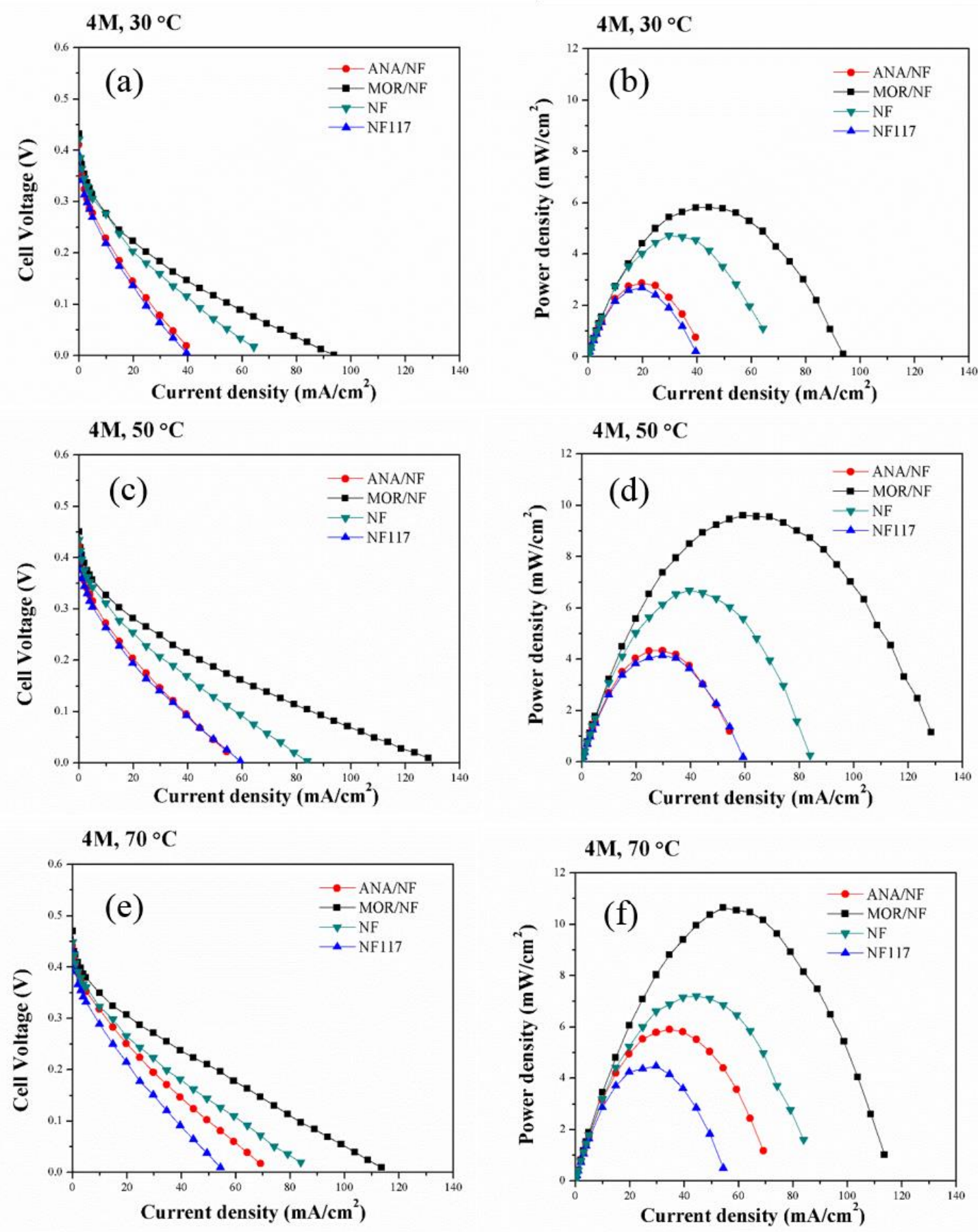

Figure 20 Polarization and power density curves highlighting the effect of preparation method of MOR/NF, ANA/NF, NF, NF117 on DMFC performance using 4 M methanol: (a) - (b) $30{ }^{\circ} \mathrm{C}$, (c) - (d) $50{ }^{\circ} \mathrm{C}$, and (e) - (f) $70^{\circ} \mathrm{C}$. 
Table 1 Summary of sorption analysis.

\begin{tabular}{llll}
\hline Sample & $\begin{array}{l}\text { Surface area }\left(\mathbf{m}^{\mathbf{2}}\right. \\
\left.\mathbf{g}^{-1}\right)\end{array}$ & $\begin{array}{l}\text { Pore } \\
\left(\mathbf{c m}^{\mathbf{3}} \mathbf{g}^{\mathbf{- 1}}\right)\end{array}$ & $\begin{array}{l}\text { volume } \\
(\AA)\end{array}$ \\
\hline ANA-s & 15.70 & 0.017 & 9.61 \\
ANA & 34.20 & 0.095 & 15.00 \\
MOR-s & 137.00 & 0.150 & 6.84 \\
MOR & 175.00 & 0.286 & 5.16 \\
\hline
\end{tabular}

Table 2 Summary of TGA data for unmodified and modified zeolite.

\begin{tabular}{|c|c|c|c|}
\hline Sample & $\begin{array}{l}\text { Weight loss }(\%) \\
20-250^{\circ} \mathrm{C}\end{array}$ & $\begin{array}{l}\text { Weight loss }(\%) \\
250-650^{\circ} \mathrm{C}\end{array}$ & MPTES (\%) \\
\hline MOR-s-H & 12 & 2 & - \\
\hline MOR-s-MPTES & 15 & 9 & 7 \\
\hline MOR-H & 11 & 2 & - \\
\hline MOR-MPTES & 10 & 7 & 5 \\
\hline ANA-s-H & 2 & 6 & - \\
\hline ANA-S-MPTES & 10 & 14 & 8 \\
\hline ANA-H & 11 & 3 & - \\
\hline ANA-MPTES & 13 & 10 & 7 \\
\hline
\end{tabular}

Table 3 Average thickness of all composite membranes, NF, and NF117.

\begin{tabular}{lll}
\hline Sample & Average thickness $(\boldsymbol{\mu m})$ & SD \\
\hline ANA/NF & 160.78 & 11.19 \\
MOR/NF & 172.89 & 8.37 \\
NF & 165.78 & 16.65 \\
NF117 & 186.67 & 3.20 \\
\hline
\end{tabular}


Table 4 Mechanical properties of composite membranes prepared by spray method

\begin{tabular}{lllll}
\hline Sample & $\begin{array}{l}\text { Thickness } \\
(\mathbf{m m})\end{array}$ & $\begin{array}{l}\text { Tensile } \\
\text { strength }(\mathbf{M P a})\end{array}$ & $\begin{array}{l}\text { Elongation } \\
(\boldsymbol{\%})\end{array}$ & $\begin{array}{l}\text { Young's } \\
\text { Modulus (MPa) }\end{array}$ \\
\hline ANA/NF & 0.15 & $18.29 \pm 0.54$ & $304.67 \pm 22.01$ & $279.17 \pm 7.32$ \\
MOR/NF & 0.18 & $16.60 \pm 0.32$ & $225.00 \pm 17.44$ & $311.57 \pm 2.94$ \\
NF & 0.15 & $21.52 \pm 0.83$ & $205.00 \pm 25.15$ & $276.81 \pm 5.05$ \\
NF117 & 0.18 & $26.65 \pm 1.22$ & $359.33 \pm 34.21$ & $236.42 \pm 7.66$ \\
\hline
\end{tabular}

Table 5 Maximum power densities obtained with the composite membranes prepared by spray method with MOR and ANA filler at various temperatures and methanol concentrations.

\begin{tabular}{lllll}
\hline \multirow{2}{*}{ Sample } & $\begin{array}{l}{[\mathbf{M e O H}]} \\
(\mathbf{M})\end{array}$ & \multicolumn{3}{c}{ Max power density $\left(\mathbf{m W} \cdot \mathbf{c m}^{-2}\right)$} \\
\cline { 4 - 5 } & & $\mathbf{3 0}{ }^{\circ} \mathbf{C}$ & $\mathbf{5 0}{ }^{\circ} \mathbf{C}$ & $\mathbf{7 0}^{\circ} \mathbf{C}$ \\
\hline ANA/NF & 4.05 & 6.13 & 7.40 \\
MOR/NF & 1 & 3.55 & 6.29 & 7.66 \\
NF & 2.59 & 5.98 & 7.54 \\
NF117 & & 2.58 & 4.15 & 5.83 \\
& & & & \\
ANA/NF & & 3.67 & 5.30 & 7.15 \\
MOR/NF & & 5.88 & 8.91 & 10.75 \\
NF & 2 & 3.26 & 5.33 & 7.35 \\
NF117 & & 2.56 & 4.24 & 5.04 \\
& & & & \\
ANA/NF & & 2.86 & 4.32 & 5.91 \\
MOR/NF & & 5.82 & 9.56 & 10.64 \\
NF & & 3.08 & 4.92 & 6.01 \\
NF117 & 4 & 2.68 & 4.15 & 4.47 \\
\hline
\end{tabular}

